\title{
Modulations of the Diurnal Cycle of Coastal Rainfall over South China Caused by the Boreal Summer Intraseasonal Oscillation
}

\author{
Xingchao Chen, Fuqing Zhang, And James H. RupPert JR. \\ Department of Meteorology and Atmospheric Science, and Center for Advanced Data Assimilation \\ and Predictability Techniques, The Pennsylvania State University, University Park, Pennsylvania
}

(Manuscript received 14 November 2018, in final form 18 January 2019)

\begin{abstract}
The influence of the boreal summer intraseasonal oscillation (BSISO) on the diurnal cycle of coastal rainfall over south China during the mei-yu (heavy rainfall) season is investigated using the OLR-based MaddenJulian oscillation index (OMI), satellite rainfall data, and atmospheric reanalysis. Results show that the meiyu season coastal rainfall is enhanced during the BSISO phase 1 (convectively active phase over the western Indian Ocean), with $25 \%$ greater rainfall than the climatological regional mean. Rainfall is suppressed during the BSISO phases 4 and 5 (convectively active phase in the Bay of Bengal and South China Sea), with negative rainfall anomalies of $39 \%$ and $46 \%$, respectively. During phase 1, the rainfall enhancement is mostly over the inland region during the afternoon, while there is little diurnal variability of the rainfall anomaly offshore. During phases 4 and 5, the rainfall suppression is considerably stronger over the offshore region in the morning, whereas stronger rainfall suppression occurs inland during the afternoon. In phase 8 , positive rainfall anomalies are found over the offshore region with a peak from the morning to the early afternoon, whereas negative rainfall anomalies are found over the inland region with the strongest suppression in the late afternoon. Analysis of phase composites and horizontal moisture advection shows that the diurnal variation of rainfall anomalies over the south China coastal area during different BSISO phases can be interpreted as the interaction between the large-scale anomalous moisture advection and the local land and sea breeze circulations.
\end{abstract}

\section{Introduction}

The south China coastal area (SCCA) is one of the biggest population and economic centers in the world, and is a region of abundant rainfall throughout the warm season (Zhou et al. 2008; Xu et al. 2009; Zheng et al. 2016). Extreme rainfall occurs frequently in this region, leading to severe flooding, numerous deaths, and major economic losses every year (Chen et al. 2014; Luo et al. 2017). This region receives most of its annual rainfall during the mei-yu (presummer rainy) season (May through June), which is the early stage of the East Asian summer monsoon. The physical mechanisms governing the mei-yu seasonal rainfall are complex. The initiation, development, and propagation of rainfall are influenced by processes across multiple scales, including the intraseasonally varying large-scale monsoonal flow (e.g., Chen et al. 2009; Chen et al. 2014; Chen et al. 2017; Du and Chen 2018), synoptic-scale disturbances (e.g., Huang et al. 2018; Zhang and Meng 2018), the land-sea

Corresponding author: Fuqing Zhang, fzhang@psu.edu breeze (e.g., X. Chen et al. 2015; Chen et al. 2017; Chen et al. 2018; Du and Rotunno 2018), coastal orography (e.g., Luo et al. 2013; Wang et al. 2014), cold pool dynamics (e.g., Chen et al. 2016), and climatological effects of urbanization (e.g., $\mathrm{Li}$ et al. 2011; S. Chen et al. 2015). Understanding and numerically forecasting rainfall in this region is therefore especially challenging. This study seeks to understand the interaction between the diurnal cycle and intraseasonal variability during the mei-yu season.

During the mei-yu season, rainfall over the SCCA exhibits a strong diurnal cycle. In the climatological mean, there is a narrow primary rainfall peak in the afternoon over the inland region and a broad secondary peak in the morning over the offshore region (X. Chen et al. 2015; Jiang et al. 2017; also shown in Fig. 1). Previous studies show that this diurnal cycle is largely controlled by the land-sea breeze circulation (Chen et al. 2016; Chen et al. 2018). The afternoon rainfall peak over the inland region is caused by the daytime inland penetration of the sea breeze and solar heating effects, whereas the morning offshore rainfall peak is caused by 

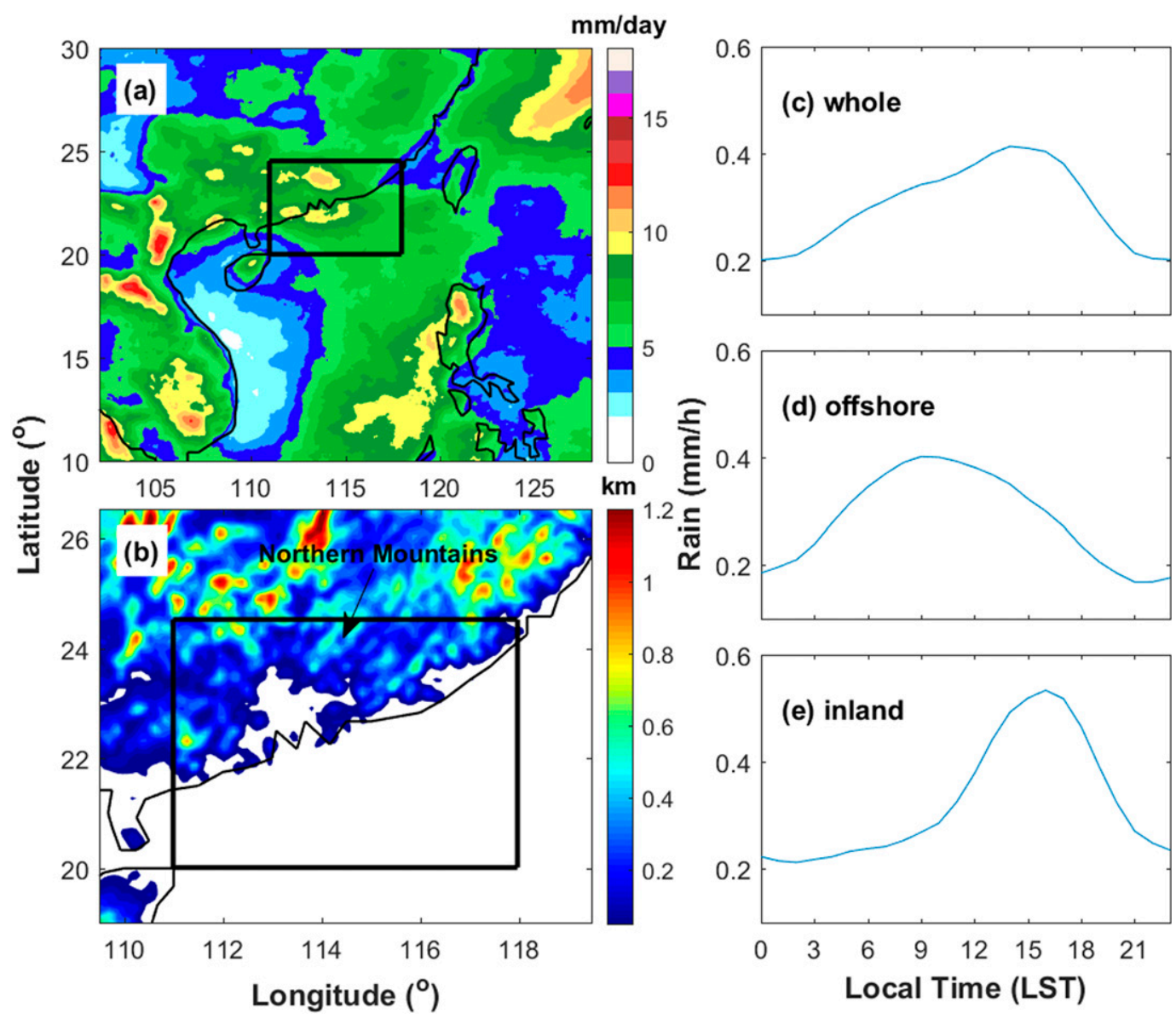

FIG. 1. (a) Spatial distributions of the daily mean rainfall during the south China mei-yu season (May-June) from 1998 to 2017 based on CMORPH. The black box shows the south China coastal area (SCCA), here and in subsequent figures. (b) Orography over the SCCA. The 20-yr averaged diurnal cycles of mei-yu season rainfall over the (c) whole SCCA, (d) offshore, and (e) inland regions.

the low-level convergence between the nocturnal land breeze and onshore monsoonal winds (Chen et al. 2016). Similar diurnal land-sea breeze signatures of precipitation can also be found over Hainan Island in the South China Sea (Zhu et al. 2017) and along the windward (west) coast of Taiwan (Kerns et al. 2010; Ruppert et al. 2013).

This mei-yu season diurnal rainfall depends on the moisture provided to the region by the background monsoonal southwesterly flow. This monsoonal flow is not steady, however, and instead exhibits pronounced intraseasonal variability, which in turn explains the strong intraseasonal variability evident in precipitation from long-term ground-based radar observations (Chen et al. 2014). Using a regional model with diurnally cyclicin-time lateral boundary conditions, Chen et al. (2017, hereafter C17) demonstrated that the intraseasonal variations of the rainfall diurnal cycle over the SCCA is closely related to the variations of the low-level monsoonal wind speed and moisture content. Their results show that the intensity of the mei-yu season coastal rainfall is especially sensitive to the moisture content of the monsoonal flow around $1.5-\mathrm{km}$ altitude $(\sim 850 \mathrm{hPa})$. They found that under low wind speed conditions the diurnal cycle of rainfall over the SCCA is characterized by prominent morning and afternoon rainfall peaks caused by the land-sea breeze, as described above. When the large-scale monsoonal wind speed is increased, however, the diurnally recurring rainfall produced by the land-sea breeze is suppressed as mechanically forced rainfall becomes more important. Under these high wind speed conditions, rainfall over the SCCA is concentrated along the coastline, with only one peak in the afternoon. However, with the idealized model setup, the intraseasonal oscillations of the rainfall diurnal cycle over the SCCA were not investigated in C17.

As a primary mode of climate variability on intraseasonal time scales (30-60 days), the boreal summer intraseasonal oscillation (BSISO) has considerable impacts 
on the East Asian summer monsoon (e.g., Ding and Chan 2005; Zhou and Chan 2005; Lau et al. 2012; Chi et al. 2015). Distinct from its eastward-propagating boreal winter counterpart, commonly known as the Madden-Julian oscillation (MJO; Madden and Julian 1971, 1972), the BSISO exhibits both northward and eastward propagation, sometimes also with westwardpropagating and standing components (Wang and Rui 1990; Zhu and Wang 1993; Wang and Xie 1997). Many previous studies have investigated the impacts of the BSISO on precipitation over the SCCA. Most of them have found that the BSISO is a major source of intraseasonal rainfall variability over the region during the warm season. For example, using surface rain gauge observations, Zhang et al. (2009) showed that the BSISO influences the summer rainfall over the SCCA through both remote (energy propagation of the Rossby wave) and local (northward shift of the anomalous meridional circulation) dynamical mechanisms. $\mathrm{Xu}$ and Rutledge (2018) demonstrated that the atmospheric circulation and rainfall amount over the SCCA are significantly different between the suppressed and active BSISO periods. Using high-resolution rain gauge-based rainfall datasets, Hsu et al. (2016) showed that the extreme rainfall over the SCCA is closely related to the northwestward propagating BSISO signals. Ren et al. (2018) found that the probability of extreme rainfall over the SCCA increases notably during the BSISO active phases because of the intensified low-level convergence and moisture transport.

Previous studies have exclusively focused on the impacts of the BSISO on the daily mean rainfall over the SCCA. Much less attention has been paid to the scale interactions between the BSISO and the coastal rainfall on the diurnal time scale. Scale interaction is defined here as the process through which the large-scale lowfrequency variability influences the regional-scale highfrequency variability of the climate system and vice versa (Slingo et al. 2003; Rauniyar and Walsh 2011). In this study, we examine how the BSISO modulates the mei-yu season rainfall over the SCCA on the diurnal time scale. The related physical mechanisms are analyzed using BSISO phase composite analysis.

\section{Data and methods}

The definition of the SCCA invoked here covers most of the south China coastline $\left(20^{\circ}-24.5^{\circ} \mathrm{N}\right.$ and $111^{\circ}$ $118^{\circ} \mathrm{E}$ ), as shown in Figs. 1a and 1b. This definition of SCCA is bigger than that in C17. The region is centered on coastal plains, with the coastline to the south and moderate-height (400-1000 m) mountains to the north (Fig. 1b). The mei-yu season over the SCCA usually begins in early May and ends in late June. Different studies have invoked different definitions of the mei-yu season (Ding and Chan 2005); however, it is defined as May through June in the present study, consistent with Xu et al. (2009) and X. Chen et al. (2015). All statistical analyses conducted for this study are performed for the mei-yu seasons from 1998 to 2017. NOAA CPC morphing technique (CMORPH) global precipitation analyses (Joyce et al. 2004) are used in this study to investigate the rainfall variability. CMORPH uses precipitation estimates derived from low-orbiter satellite microwave observations, which are horizontally translated by assuming propagation information from geostationary satellite IR observations. The spatial and temporal resolutions of CMORPH are $0.07277^{\circ}(8 \mathrm{~km}$ at the equator) and $30 \mathrm{~min}$. Chen et al. (2018) compared different satellite rainfall estimates to the surface rain gauge observations. Their results show that CMORPH analyses can realistically capture the diurnal features of rainfall over the SCCA, while an underestimation of the morning rainfall near the coastline can be found in the dataset. In addition, CMORPH provides more spatial detail of rainfall than other satellite rainfall analyses (e.g., the Tropical Rainfall Measuring Mission) due to its higher spatial resolution. The ERA-Interim (ERA-I) reanalysis (Dee et al. 2011) at $0.75^{\circ} \times 0.75^{\circ}$ spatial resolution is used for calculating the low-level moisture advection and composite analysis, which utilizes 6-hourly horizontal winds, vertical velocity, temperature, and specific humidity. One should note that the diurnal variation of winds and moisture derived from reanalysis data is not always accurate, because the diurnal mesoscale circulations may not be adequately resolved in the current-generation reanalysis data assimilation system with rather coarse horizontal grid spacing and the use of a hydrostatic dynamical core. Further, the temporal resolution of the reanalysis data (usually 4 times per day) may not be sufficient to study the full extent of the diurnal cycles. We therefore primarily rely upon this reanalysis dataset to assess intraseasonal patterns. The study also uses the daily outgoing longwave radiation (OLR) Climate Data Record (CDR) data derived from High-Resolution Infrared Sounder radiance observations onboard the NOAA TIROS-N series and MetOp satellites (Lee et al. 2007) to investigate the propagating features of the BSISO during the mei-yu season. The spatial resolution of the OLR CDR data is $1^{\circ}$.

The BSISO phase is determined by the OLR MJO index (OMI) developed by Kiladis et al. (2014). Wang et al. (2018) compared four widely used intraseasonal oscillation indices. They demonstrated that OMI effectively captures both northward and eastward propagation of the BSISO to a greater degree than the other ISO 
indices they examined. A strong BSISO event is defined here when the amplitude of the OMI index exceeds 1.0 (Kiladis et al. 2014), which results in a total of 734 days, with the remaining 486 days being in the weak phase of the BSISO. Only the strong BSISO events are considered in the study. Each event is broken into phases 1-8. Over the study period, the total numbers of days falling into each of the BSISO phases $1-8$ are $60,79,136,93,74$, 97, 110, and 85 days, respectively. Daily (and hourly) anomalies of rainfall, OLR, and other atmospheric variables are calculated by subtracting the daily (and hourly) climatological mean of the 20 mei-yu seasons from the original data (e.g., the daily rainfall anomaly on 1 May 1998 is the rainfall on that date minus the $20-y r$ mean rainfall on $1 \mathrm{May}$, and likewise for a given hour of the day). This allows the seasonal transition signal associated with the BSISO (Chi et al. 2015) to be removed. Phase composites are made according to the OMI index for phases 1-8.

In $\mathrm{C} 17$, the moisture advection around $850 \mathrm{hPa}$ $(\sim 1.5 \mathrm{~km})$ is found to be crucial to the rainfall intensity over the SCCA during the mei-yu season. Anomalous horizontal moisture advection (MADV) associated with the BSISO is decomposed here by separating each variable into a basic state and an anomalous component associated with the BSISO:

$$
\begin{aligned}
\text { MADV }= & \left(-u^{\prime} \frac{\partial \bar{q}}{\partial x}-v^{\prime} \frac{\partial \bar{q}}{\partial y}\right)+\left(-\bar{u} \frac{\partial q^{\prime}}{\partial x}-\bar{v} \frac{\partial q^{\prime}}{\partial y}\right) \\
& +\left(-u^{\prime} \frac{\partial q^{\prime}}{\partial x}-v^{\prime} \frac{\partial q^{\prime}}{\partial y}\right),
\end{aligned}
$$

where $\bar{u}$ and $\bar{v}$ denote zonal and meridional background mean winds, respectively; $u^{\prime}$ and $v^{\prime}$ indicate the zonal and meridional anomalous winds associated with the BSISO. Similarly, $\bar{q}$ and $q^{\prime}$ are the background mean and the BSISO anomalous specific humidity, respectively. Term 1 on the right-hand side (RHS) of Eq. (1) is the advection of the background mean moisture by the BSISO anomalous wind. Term 2 indicates the advection of the BSISO anomalous moisture by the background mean wind. Term 3 is the advection of the BSISO anomalous moisture by the BSISO anomalous wind. The influences of the BSISO on the SCCA rainfall and MADV will be discussed in section 5 .

\section{Diurnal cycle of the mei-yu season coastal rainfall over south China}

Figure 1a displays the spatial distribution of the daily mean total precipitation during the 1998-2017 mei-yu seasons. The SCCA subset region is shown by the black box. Two major rainfall centers can be seen over the
SCCA during the mei-yu season, with one center located on the windward (southwestern) slope of northern mountainous area and the other center located offshore parallel to the coastline. Another smaller rainfall center can be found on the inland side of the southwest coast in the SCCA, which is closely related to the orographic lifting effects of the coastal terrain (Wang et al. 2014). The spatial distribution of the mei-yu season rainfall over the SCCA is consistent with the 3-yr ground-based radar observations (X. Chen et al. 2015). The diurnal cycle of mei-yu season hourly rainfall averaged over the SCCA is shown in Fig. 1c. A prominent afternoon rainfall peak can be found around 1500 LST (local standard time). The diurnal pattern is similar to the ground-based radar observations (X. Chen et al. 2015), while the morning rainfall is a little bit weaker than the radar observations (radar observations also show a weak secondary peak around 0900 LST) because CMORPH tends to underestimate the morning rainfall associated with the land breeze (Chen et al. 2018). This difference may also be partially induced by the different observational lengths of CMORPH and ground-based radar observations. The diurnal cycles of rainfall averaged separately over the offshore and inland regions of the SCCA are shown in Figs. 1d and 1e. These panels show that rainfall over the offshore region begins to increase from evening (after 2100 LST) and reaches a peak near 0900 LST (Fig. 1d). On the other hand, the afternoon rainfall peak of the SCCA is largely due to the inland precipitation. The rainfall over the inland region increases very slightly from 0300 to 0900 LST, and increases more rapidly from 0900 LST to the narrow peak at 1600 LST (Fig. 1e).

The mei-yu season rainfall over the SCCA is sensitive to the strength and moisture content of the prevailing low-level monsoonal wind around $850 \mathrm{hPa}$ (C17). Figure 2a displays the mean horizontal winds at $850 \mathrm{hPa}$ during the mei-yu season. The southerly monsoonal wind transports moisture from the South China Sea to the SCCA, and provides a favorable environment for heavy rainfall. The diurnal variations of $10-\mathrm{m}$ perturbation winds and 2-m perturbation temperature are shown in Figs. $2 b$ and $2 c$. Figure $2 b$ shows the differences between 0800 and 2000 LST, which is the developing period of the offshore morning rainfall peak (Fig. 1d). Figure 2c shows the differences between 1400 and 0800 LST, which corresponds to the establishing period of the inland afternoon rainfall peak (Fig. 1e). Because the heat capacity of land is smaller than that of ocean, stronger diurnal variations of surface temperature occur over the inland region. As a result, the land breeze develops from evening to morning (Fig. 2b), and the sea breeze establishes from morning to afternoon (Fig. 2c). The land breeze is much stronger over the offshore region while the sea breeze is stronger over the inland 

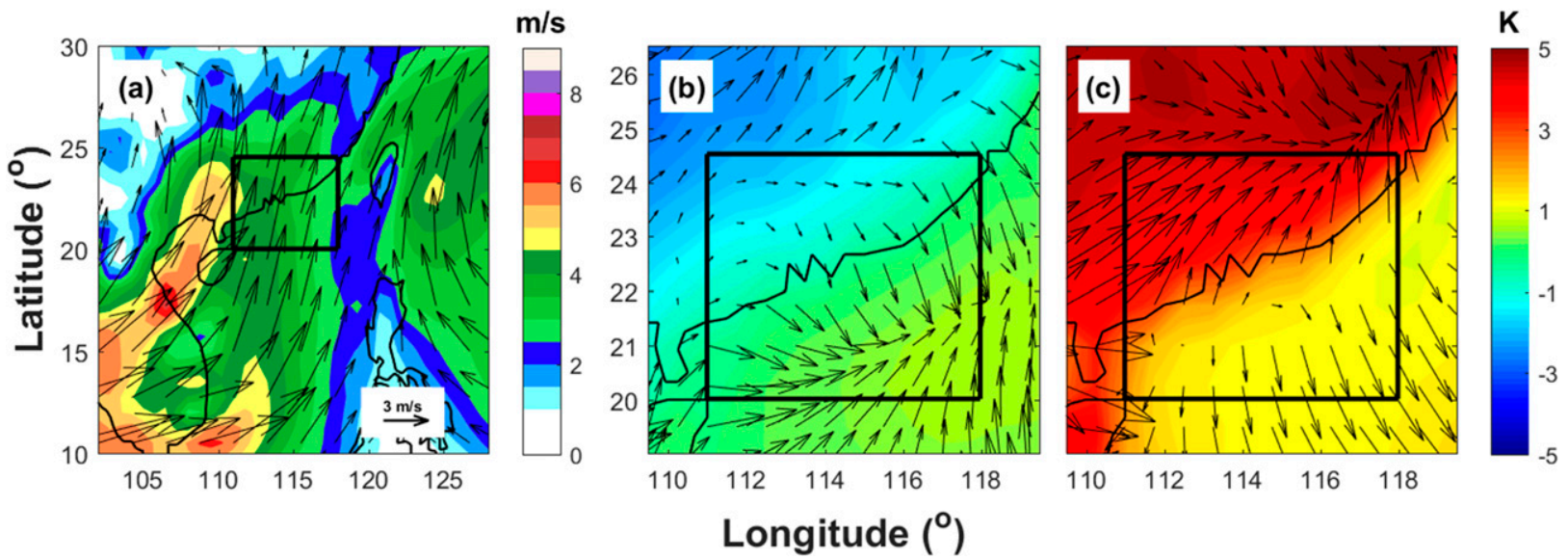

FIG. 2. (a) The mean wind speed (color shading) and wind (arrow) fields at $850 \mathrm{hPa}$ for 20 mei-yu seasons (1998-2017) from ERA-I. The 10-m wind vector (arrow) and 2-m surface temperature differences between (b) 0800 and 2000 LST (0800 - 2000 LST) and (c) 1400 and 0800 LST $(1400-0800$ LST).

region. These features are consistent with the idealized simulations in C17 and Chen et al. (2016).

Figure 3 shows the diurnal cycle of rainfall over the SCCA during the mei-yu season. Consistent with Fig. 1d, the offshore rainfall begins to increase from 2100 LST and reaches its peak around 0900 LST. The nocturnal offshore rainfall line is parallel to the coast and exhibits an offshore direction of propagation from the evening to morning due to the development of the land breeze and the propagation of inertia-gravity waves ( $\mathrm{Du}$ and Rotunno 2018). A weaker nocturnal rainfall center can also be found over the windward slopes of the inland northern mountains (Fig. 1b) during this period, which owes to the inertial oscillation of the ageostrophic wind in the boundary layer (X. Chen et al. 2015). Specifically, the inertial oscillation leads to enhanced southwesterly flow overnight, which enhances lift along the windward slopes of these inland northern mountains. From noon (1200 LST) to the early afternoon (1500 LST), the offshore rainfall line decays gradually. On the other hand, inland precipitation increases and reaches its maximum intensity around 1500-1800 LST. The afternoon inland rainfall is induced by the solar heating effects, inland penetration of the sea-breeze front, and inland propagation of inertia-gravity waves (Chen et al. 2016; Du and Rotunno 2018). The inland rainfall decays from late afternoon (1800 LST) to evening (2100 LST). In general, the diurnal cycle of rainfall over the SCCA is closely related to the diurnal variations of the local land-sea breeze circulation during the mei-yu season.

\section{Propagation of the BSISO}

Figure 4 shows the BSISO phase composites of the OLR and 500-hPa wind anomalies averaged over the
1998-2017 mei-yu seasons. In addition to eastward propagation, the BSISO also exhibits clear northward propagation during the mei-yu season. In phase 1 , the convectively active phase of the BSISO is located over the tropical western Indian Ocean. Convection from southern India to the South China Sea is suppressed in this phase. At the same time, convective activity over the SCCA and the adjacent ocean area is enhanced due to the northward propagation of the previous BSISO event. An anomalous cyclone is situated near the SCCA at $500 \mathrm{hPa}$, which may be induced by the strengthened convective latent heating over the region and/or the northeastward-propagating Rossby wave train (Hung et al. 2014). From phases 2 to 4, the convectively active phase of the BSISO propagates from the western Indian Ocean to the Bay of Bengal and Indochina, while the convectively suppressed phase shifts northward and eastward. In phases 4 and 5, the convectively suppressed phase of the BSISO reaches the SCCA and its adjacent ocean area. Correspondingly, an anomalous anticyclone appears near the SCCA at $500 \mathrm{hPa}$ (in phase 5). The convectively active phase of the BSISO is located over the South China Sea in phase 5. From phases 5 to 2, the convectively active phase propagates northward from the tropics into the middle latitudes as a new active phase simultaneously develops over the western Indian Ocean.

The northward propagation of the BSISO averaged along the $111^{\circ}-118^{\circ} \mathrm{E}$ (the SCCA) longitude band is shown in Fig. 5 through anomalous vertical velocity and meridional wind fields. In phase 1 , anomalous downward motion associated with the BSISO convectively suppressed phase is situated around $10^{\circ} \mathrm{N}$. This downward motion induces divergence in the lower troposphere (below $1.5 \mathrm{~km}$ ) and enhanced low-level southerly 


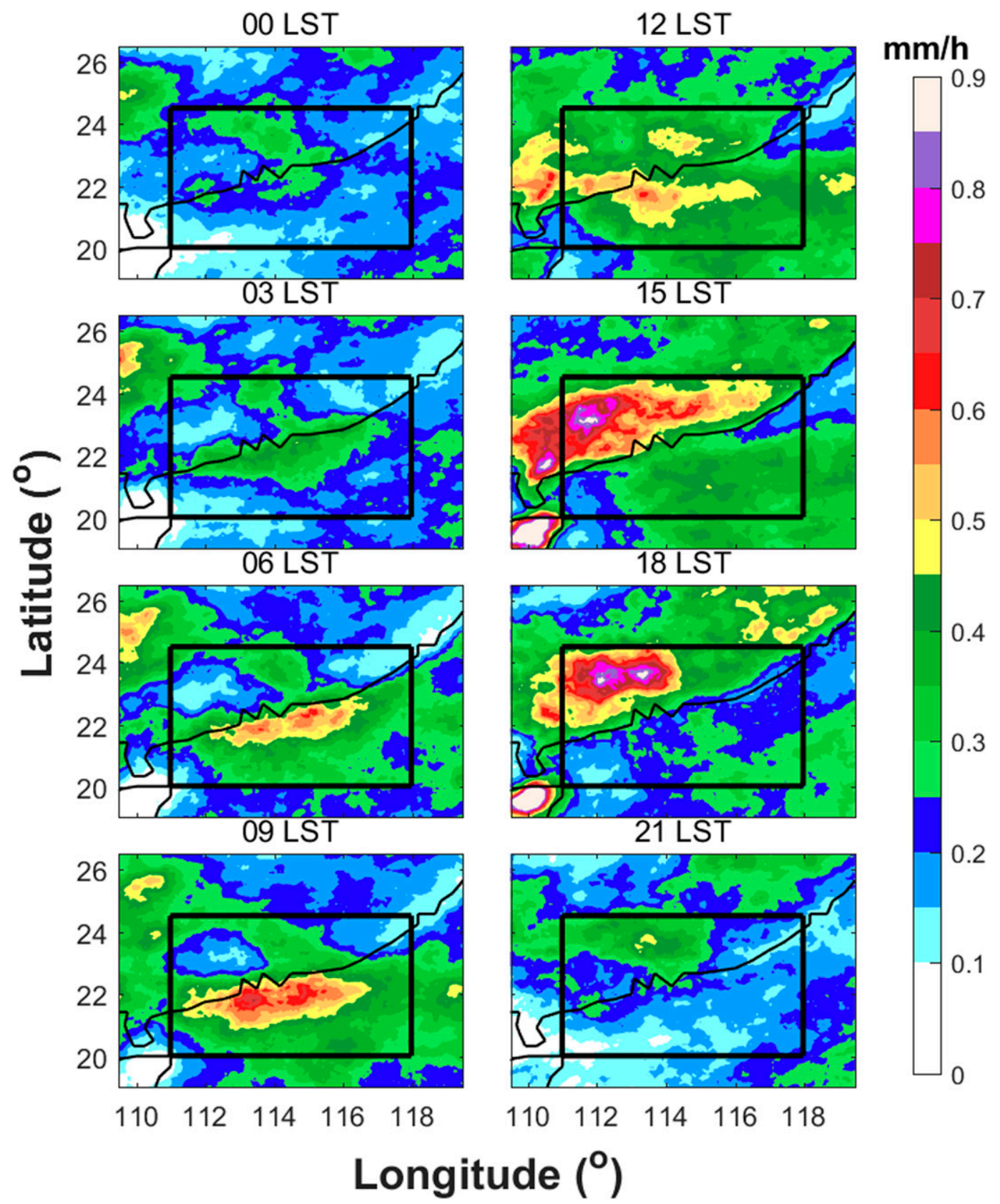

FIG. 3. Diurnal variations of hourly rainfall averaged over 1998-2017 mei-yu seasons.

wind from the South China Sea to the SCCA. The convectively suppressed phase of the BSISO weakens and propagates northward from phases 1 to 5 . It reaches the SCCA in phase 5. In phase 5, anomalous upward motion associated with the BSISO convectively active phase is situated between $10^{\circ}$ and $20^{\circ} \mathrm{N}$. This upward motion induces convergence in the lower troposphere and weakens the low-level southerly wind from the South China Sea to the SCCA. Similar to the convectively suppressed phase, the BSISO convectively active phase weakens and propagates northward from phases 5 to 1 , and reaches the SCCA in phase 1 .

\section{Influences of the BSISO on the coastal rainfall diurnal cycle}

In correspondence with the northeastward propagation of the BSISO, rainfall over the SCCA is considerably enhanced during phase 1 , and is considerably reduced during phases 4 and 5 (Fig. 6). The daily rainfall 


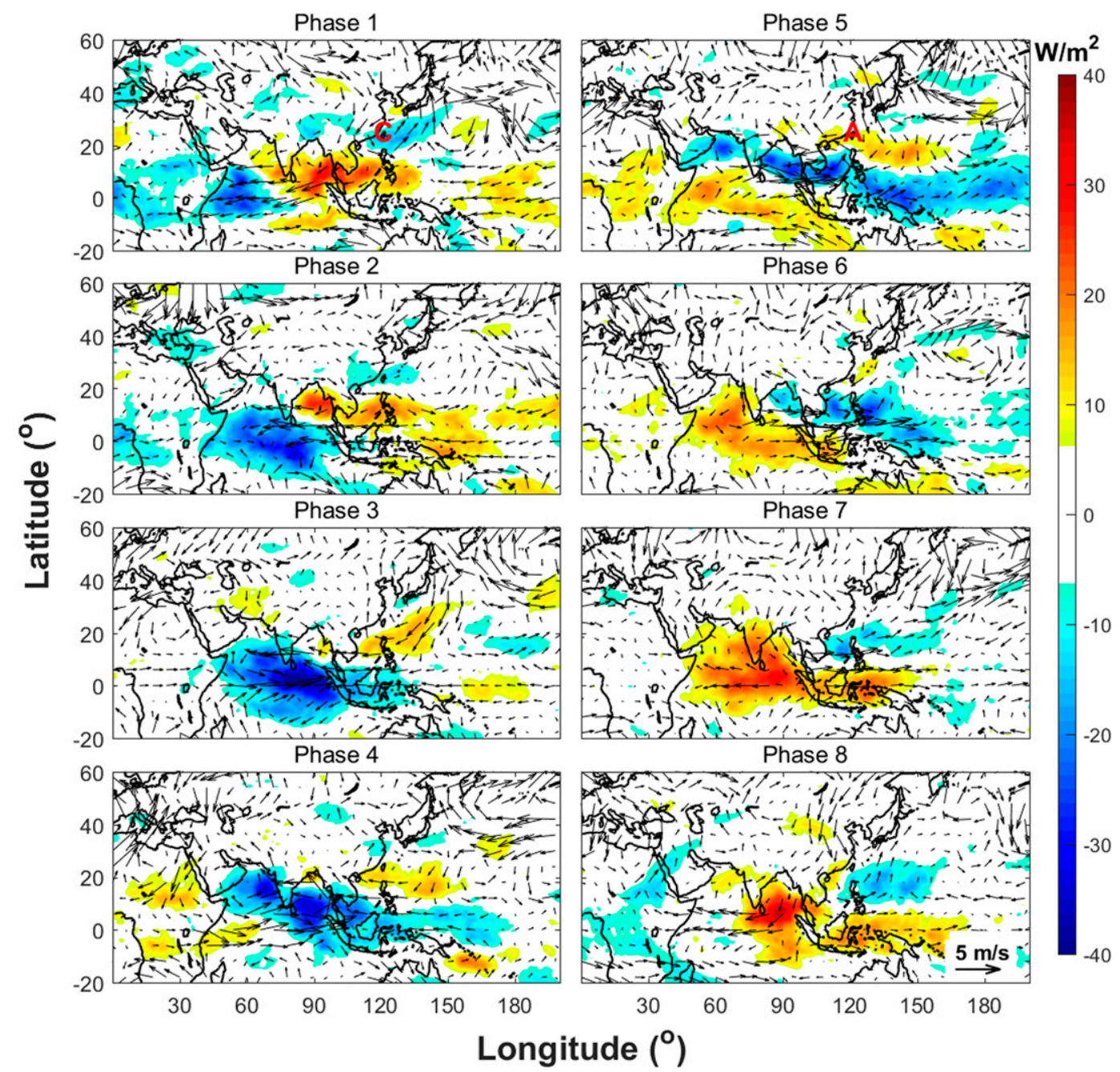

FIG. 4. Composites of OLR (color shading) and 500-hPa wind (arrow) anomalies for BSISO phases 1-8 during 1998-2017 mei-yu seasons. The letters A and C stand for anticyclone and cyclone, respectively.

anomalies averaged over the SCCA are $1.83,-2.86$, and $-3.38 \mathrm{~mm} \mathrm{day}^{-1}$ during phases 1,4 , and 5 , which are approximately $25 \%, 39 \%$, and $46 \%$ of the climatological mean magnitude of the mei-yu season rainfall over the SCCA $\left(7.26 \mathrm{~mm} \mathrm{day}^{-1}\right)$. The rainfall anomalies in other BSISO phases are all below $9 \%$ of the mean in magnitude. The daily-averaged anomalous horizontal winds at $850 \mathrm{hPa}$ for each BSISO phases are also shown in Fig. 6 . In phase 1, an anomalous anticyclone can be found over the central South China Sea, which corresponds with the suppressed convective activity over the region (Fig. 5). The southwesterly wind over the SCCA is strengthened during this phase. Also, the BSISO enhances the westerly wind from Indochina to the SCCA. In phase 2, the anomalous low-level wind pattern is similar to phase 1 , while the southerly flow component is increased and the rainfall is slightly reduced. From phases 3 to 5, the anomalous winds over the SCCA turn from southerly to easterly. In phase 5, a clear dry phase can be found over the SCCA with convective activity enhanced in the South China Sea. At the same time, an anomalous cyclone is situated over the South China Sea, with anomalous easterly flow over the SCCA. The suppression of rainfall over the SCCA gradually weakens from phases 6 to 8 , while the low-level wind over the SCCA turns from easterly to northerly. In phase 8, rainfall over the SCCA inland region is suppressed while rainfall over the SCCA offshore region is enhanced.

Figure 7 displays the diurnal variation of rainfall anomalies over the SCCA during each BSISO phase. We find that the diurnally varying patterns of rainfall anomalies are closely related to the low-level anomalous winds. During phases 1 and 2, when there is anomalous southwesterly flow in the SCCA, a preferential rainfall enhancement can be found in the afternoon. However, when easterly anomalous wind dominates over the 


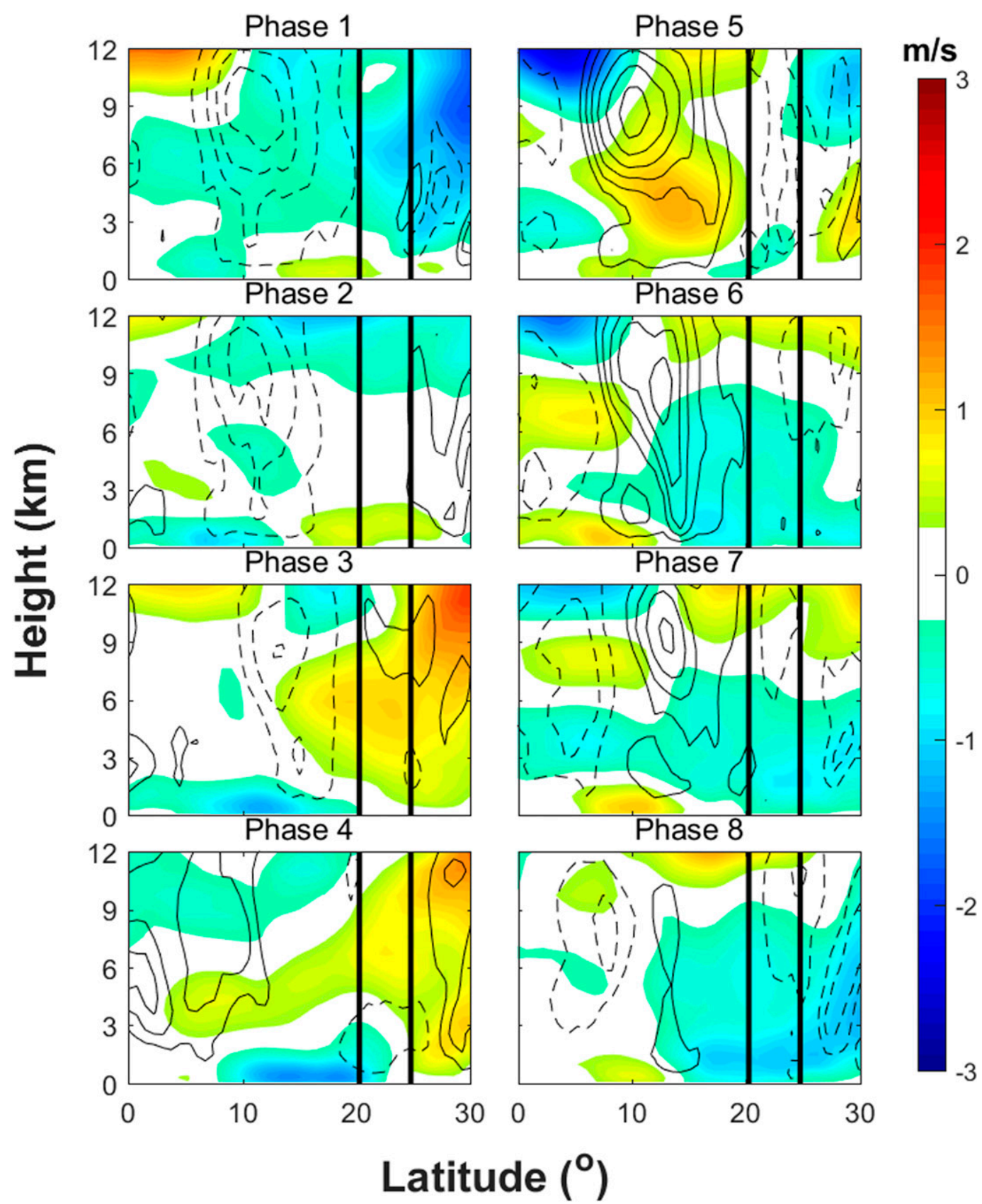

FIG. 5. Composites of meridional wind (color shading) and vertical velocity (black contours) anomalies averaged over the $111^{\circ}-118^{\circ} \mathrm{E}$ (the SCCA) longitude band during 1998-2017 mei-yu seasons. The positive vertical velocity anomalies are shown in solid contours, and the negative vertical velocity anomalies are shown in dashed contours. The contour interval is $0.01 \mathrm{~m} \mathrm{~s}^{-1}$. The bold black lines denote the latitude bands of the SCCA $\left(20^{\circ}\right.$ and $\left.24.5^{\circ} \mathrm{N}\right)$.

SCCA in phases 4 to 5 , stronger rainfall suppression can be found from the morning to the afternoon. The anomalous rainfall during the transition phases 3,6 , and 7 show little diurnal variability. In phase 8 , the SCCA is impacted by anomalous northerly wind (Fig. 6). The rainfall over the SCCA is notably enhanced around 1200 LST during this phase.
The diurnal variations of rainfall anomalies over the SCCA offshore and inland regions are shown separately in Figs. 8 and 9. We find that the afternoon peak of the positive rainfall anomalies during phases 1 and 2 is largely due to the rainfall anomalies over the inland region, which is characterized by a prominent afternoon enhancement (Fig. 9). However, the rainfall anomalies 


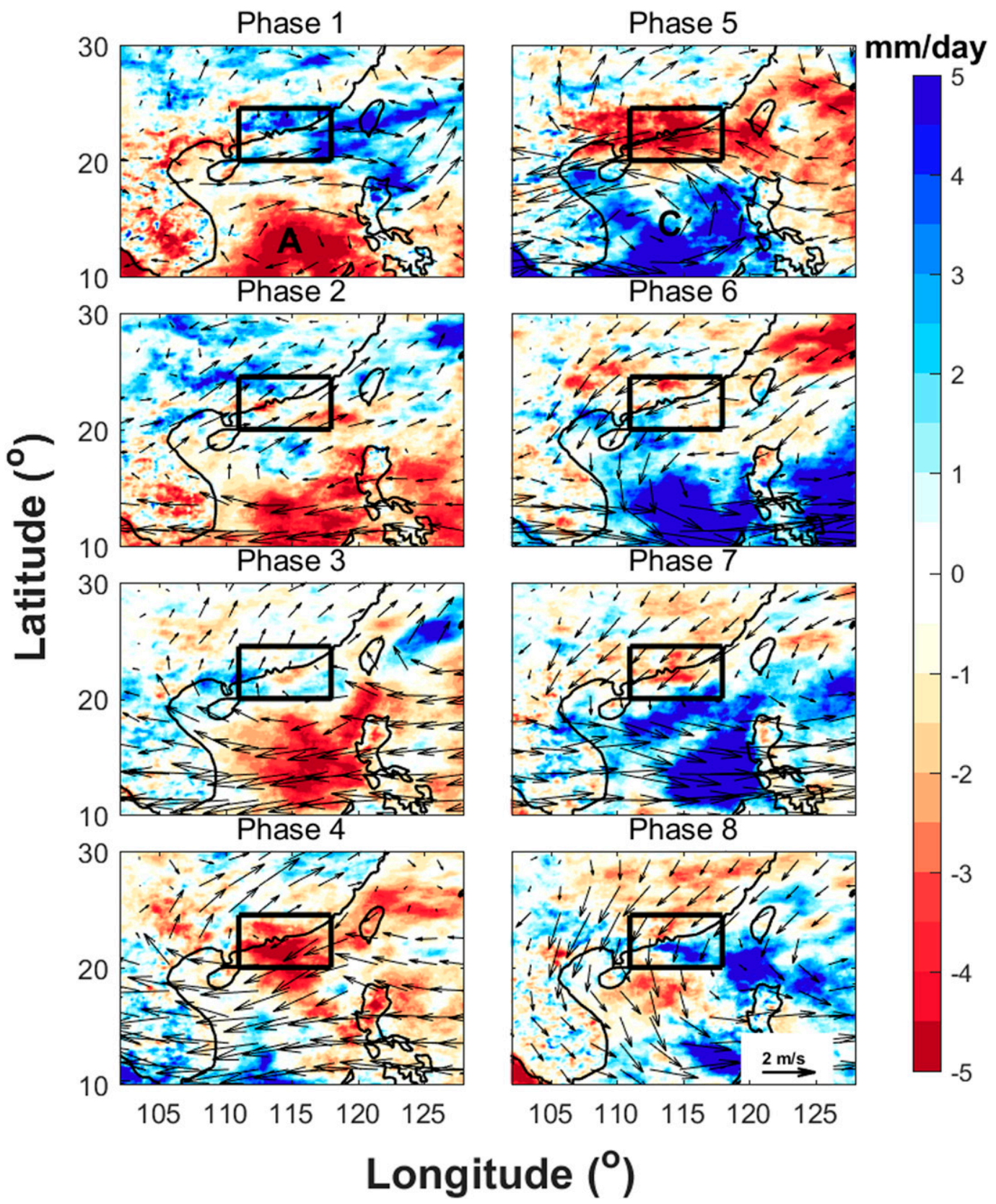

FIG. 6. Composites of rainfall (color shading) and 850-hPa wind (arrow) anomalies for BSISO phases 1-8 during 1998-2017 mei-yu seasons. The letters A and C stand for anticyclone and cyclone, respectively.

over the offshore region show little diurnal variability in comparison to the inland region (Fig. 8). During phases 4 and 5 , the stronger morning-to-afternoon rainfall suppression over the SCCA is due to the rainfall anomalies over both the offshore and the inland regions. The rainfall suppression is stronger in the morning over the offshore region (Fig. 8) and is stronger during the afternoon over the inland region (Fig. 9). In phase 8, the noon rainfall positive peak is largely due to the rainfall enhancement from the morning to the afternoon in the offshore region (Fig. 8). Rainfall anomalies during phases 3,6 , and 7 show weaker diurnal variability over both the offshore and inland regions, except for an anomalous rainfall minimum that can be found in the evening during phase 7 . The rest of this study will focus on the diurnal cycle of anomalous rainfall during the following three phases: phase 1 (the SCCA convectively active phase with stronger inland afternoon rainfall enhancement), phase 5 (the SCCA convectively suppressed phase with a stronger morning rainfall suppression over the 


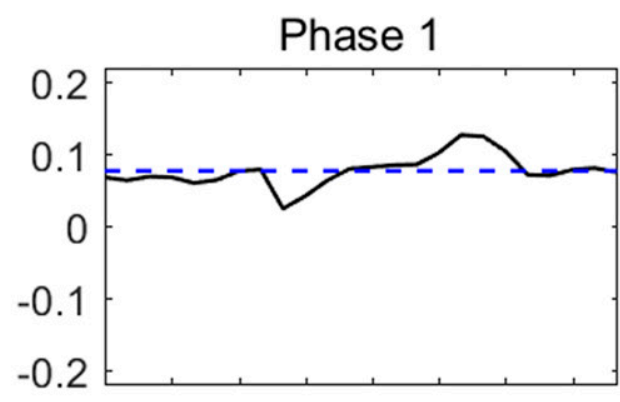

Phase 2
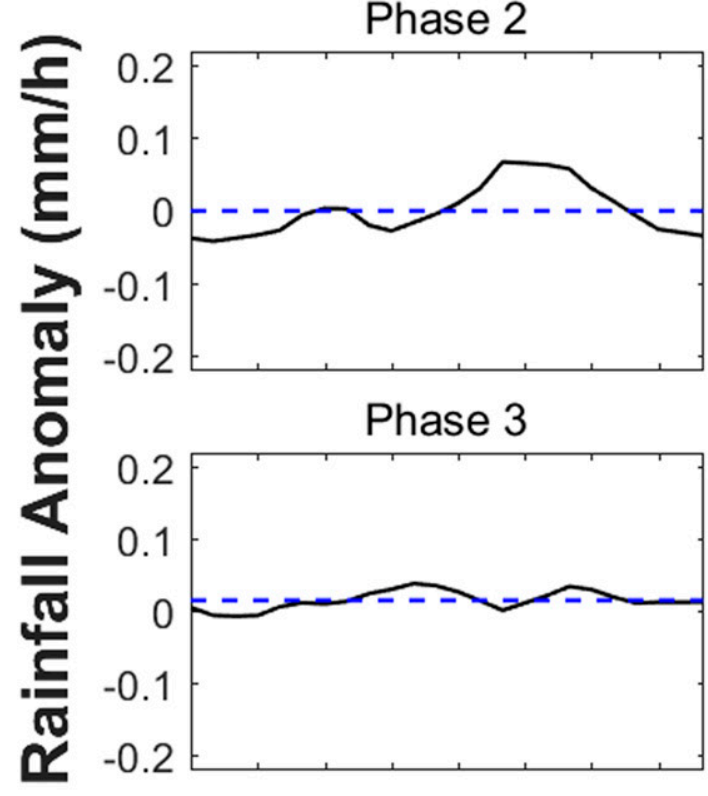

Phase 3

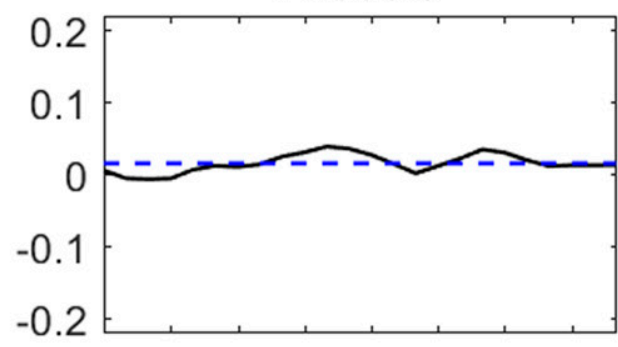

Phase 4

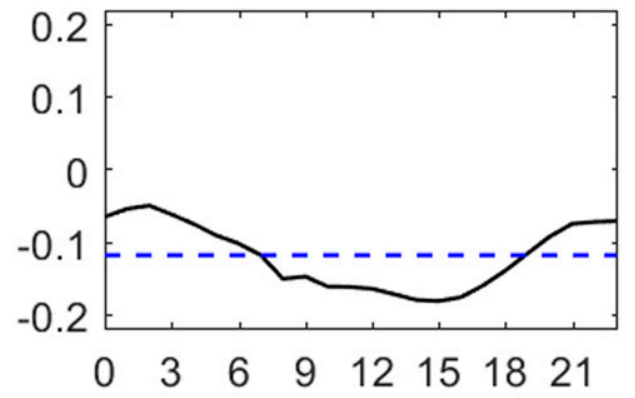

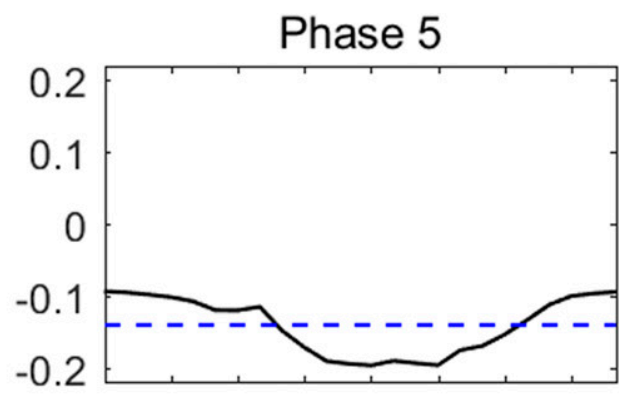

Phase 6

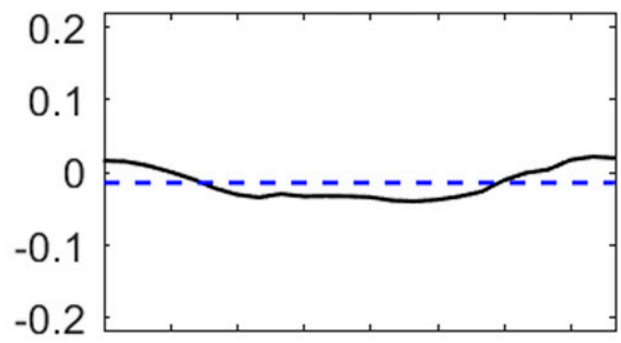

Phase 7

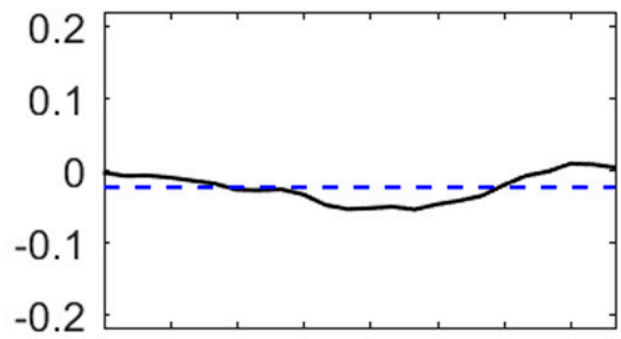

Phase 8

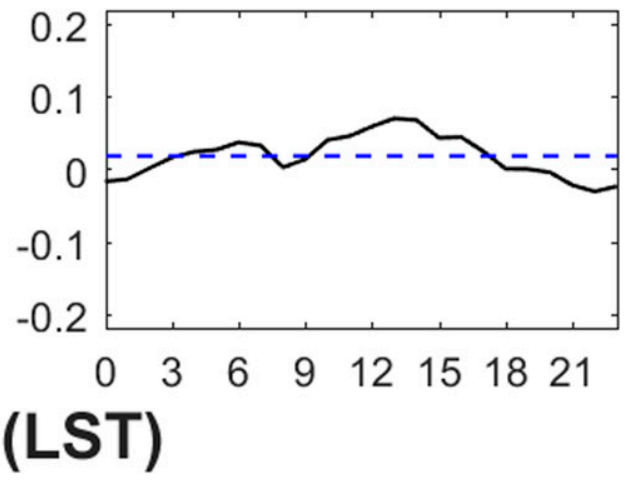

FIG. 7. Diurnal variations of rainfall anomalies over the SCCA for BSISO phases $1-8$. The blue dashed lines show the daily mean rainfall anomalies for each BSISO phase.

offshore region and a stronger afternoon rainfall suppression over the inland region), and phase 8 (the SCCA convective transition phase with a notable offshore rainfall enhancement from the morning to the afternoon).

Figure 10 shows the diurnal variations of the spatial distributions of anomalous rainfall during phase 1 . From the night to the early morning (0000-0300 LST), an inland positive anomalous rainfall center can be found on the windward slope of the northern mountainous area of the SCCA, which corresponds to the enhanced nocturnal orographic rainfall associated with the inertial oscillation. The offshore rainfall associated with the land breeze does not show clear enhancement or suppression during this time period. The nocturnal inland positive anomalous rainfall center disappears after 0600 LST. 


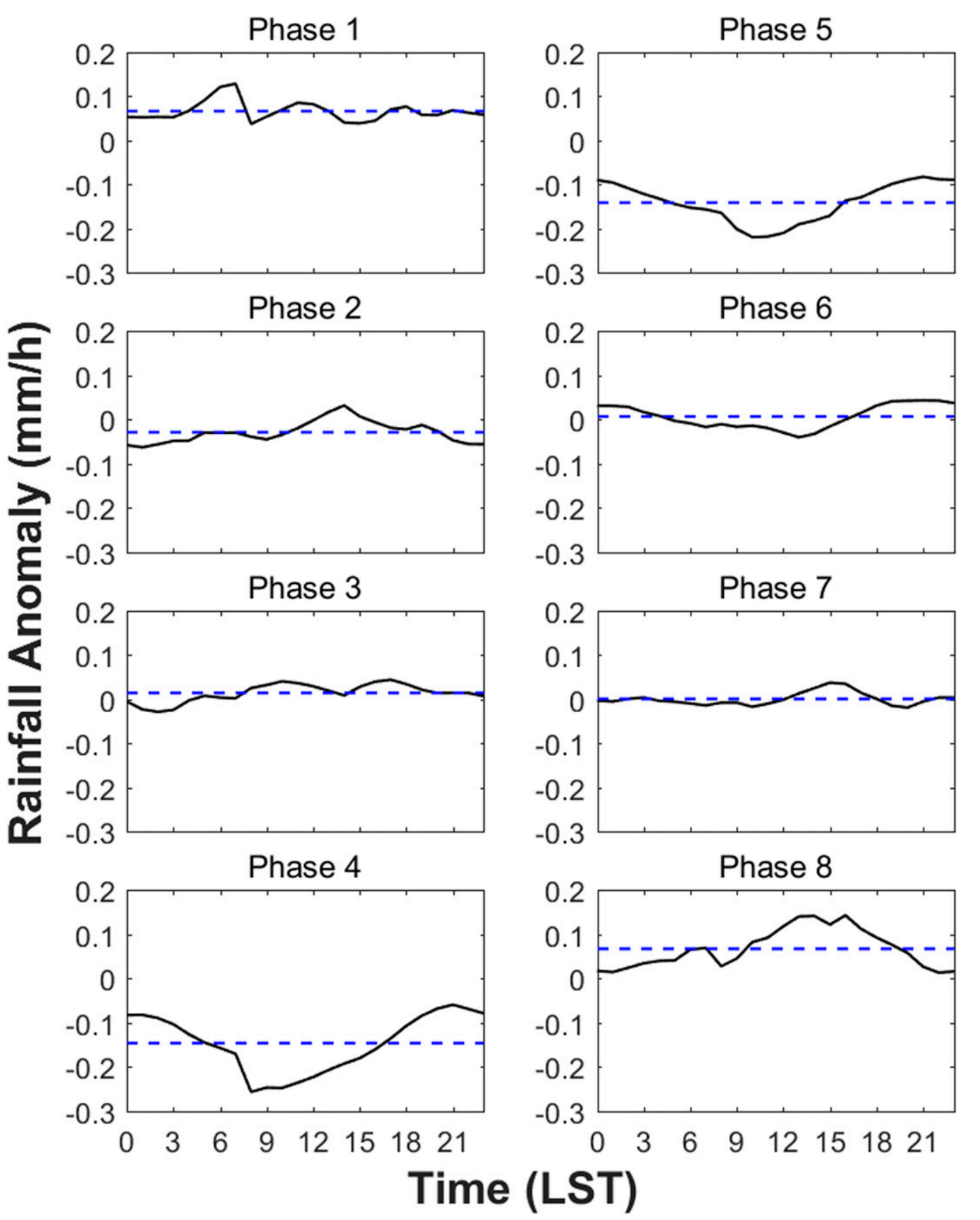

FIG. 8. As in Fig. 7, but for the offshore region in the SCCA.

At 0900 LST, negative rainfall anomalies prevail over the western offshore region while positive rainfall anomalies occur over the eastern offshore region. From noon to the afternoon (1200-1500 LST), a strong enhancement of rainfall can be found over the SCCA inland region. However, the anomalous rainfall over the offshore region is very weak with values between -0.2 and $0.2 \mathrm{~mm} \mathrm{~h}^{-1}$. The enhanced rainfall over the inland region weakens from the late afternoon $(1800 \mathrm{LST})$ to the evening (2100 LST). In general, the inland anomalous rainfall shows a clear diurnal cycle with a prominent enhancement during the early afternoon in phase 1 . However, the anomalous rainfall over the offshore region is weaker and shows little diurnal cycle in this phase.

In phase 5, a clear suppression of the offshore rainfall can be found from the night to the morning (0000-0900 LST), with an area-averaged rainfall minimum around $-0.22 \mathrm{~mm} \mathrm{~h}^{-1}$ around 0900 LST (Fig. 11). Comparison 


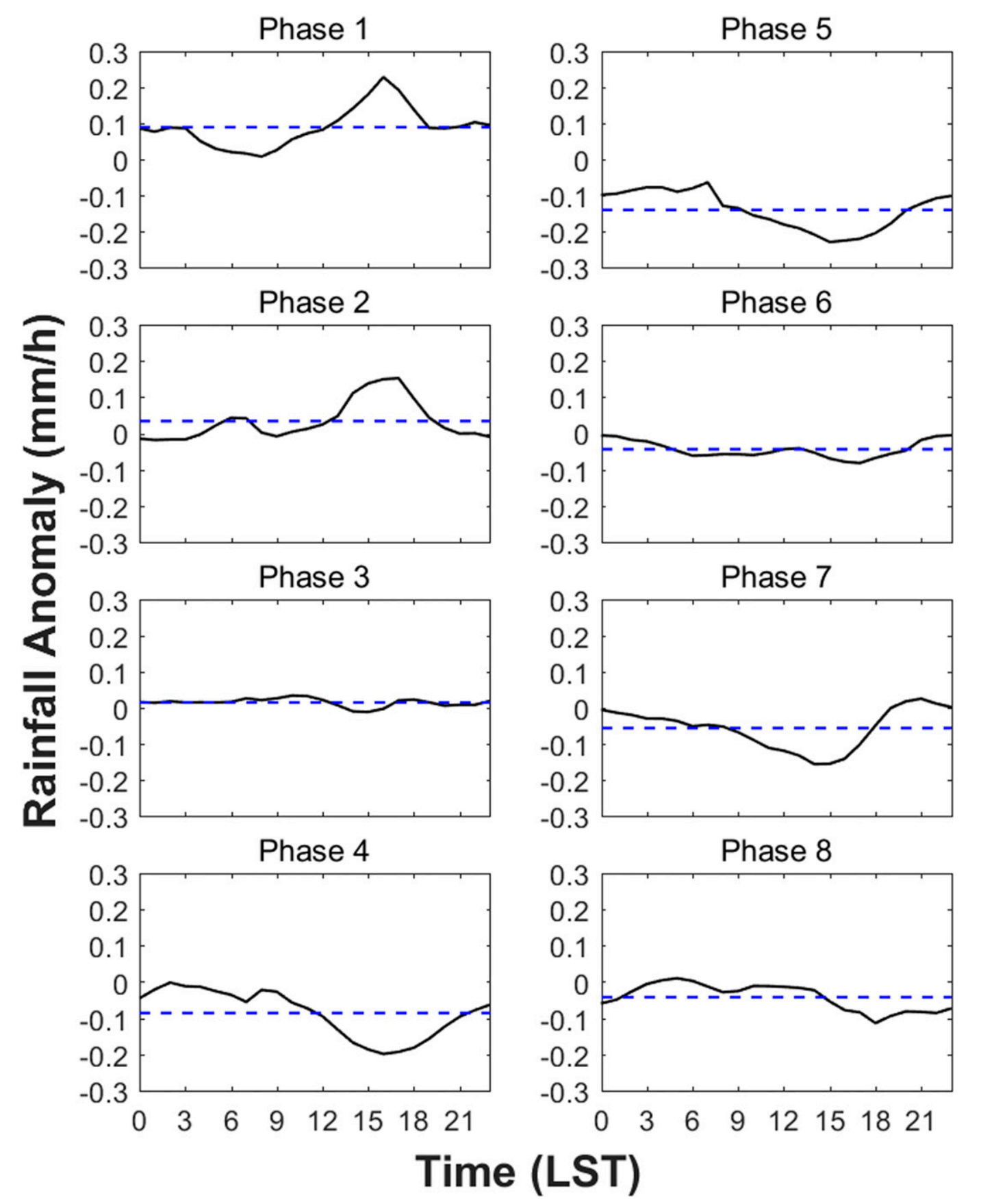

FIG. 9. As in Fig. 7, but for the inland region in the SCCA.

between the evolutions of the offshore negative rainfall anomalies with the development of the nocturnal precipitation caused by the land breeze in Fig. 3 indicates that the land breeze induced offshore rainfall is suppressed during this phase. From noon to the afternoon (1200-1800 LST), the inland rainfall is also suppressed dramatically, with the mean inland rainfall anomaly reaching $-0.23 \mathrm{~mm} \mathrm{~h}^{-1}$ at 1500 LST. This indicates that the afternoon rainfall induced by the sea breeze penetration and solar heating effects is also suppressed in this phase. The negative inland rainfall anomalies decay from the late afternoon to the evening (1800-2100 LST; Fig. 11).

During phase 8 , the land breeze related offshore rainfall is enhanced notably. Positive offshore rainfall anomalies can be noted from the night to the morning (0000-0900 LST; Fig. 12). In addition, the positive rainfall anomalies exhibit a clear offshore propagation 


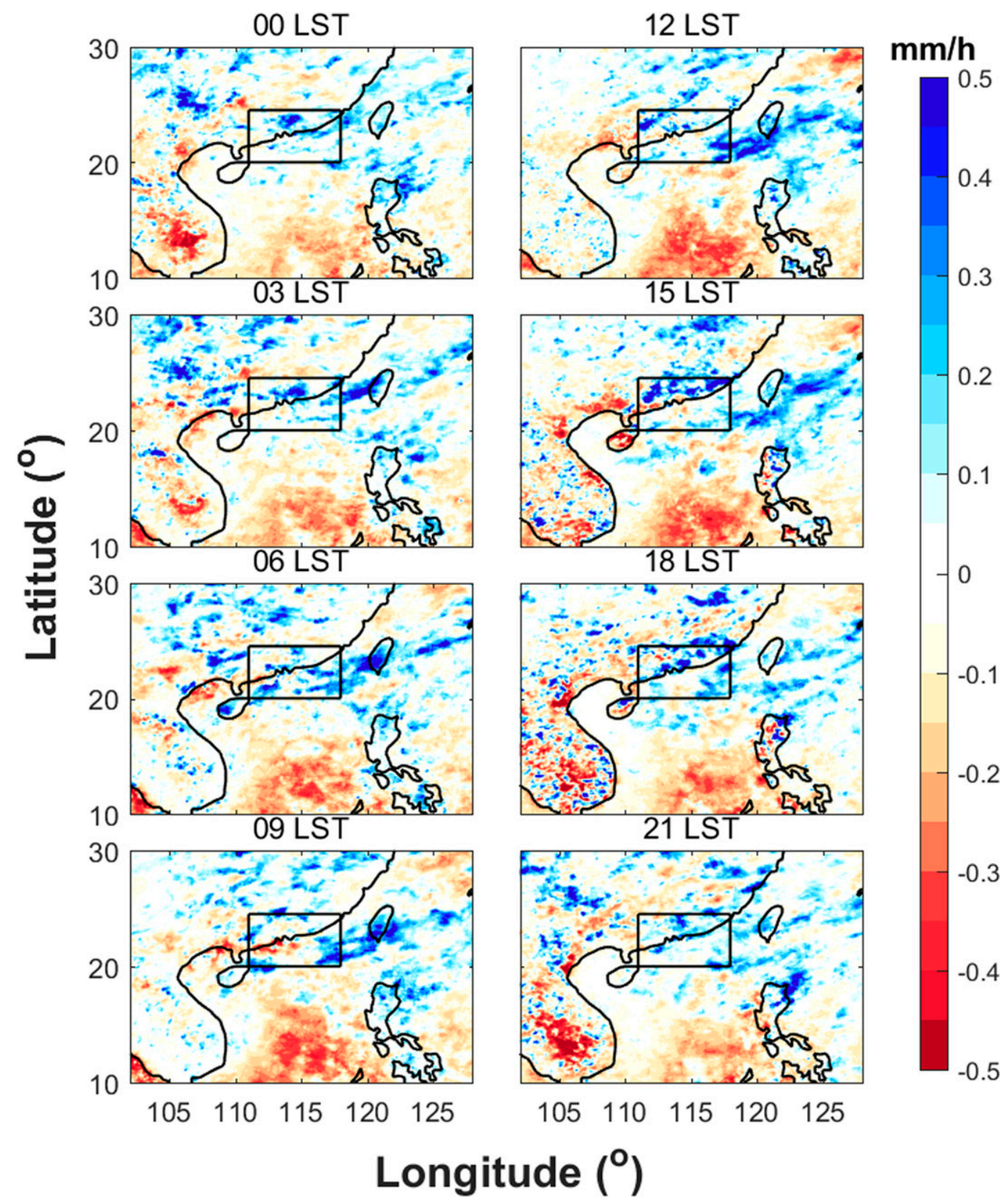

FIG. 10. Composite diurnal cycle of hourly rainfall anomalies for BSISO phase 1.

(southeastward) from noon to the afternoon (1200-1800 LST). This propagating rainfall feature peaks around midday and weakens in the afternoon, which explains the near-noon peak in the diurnal rainfall anomaly in the offshore average for phase 8 (Fig. 8). This indicates that the land breeze related rainfall is stronger and has a longer lifetime during phase 8 . In the afternoon (15001800 LST), on the other hand, the precipitation is notably suppressed over the inland region. The anomalous rainfall signals over both the inland and the offshore regions weaken further in the evening (2100 LST).
The impacts of the BSISO on the low-level horizontal moisture advection are quantified next (see section 2 for details on the calculation). Figure 13 displays the daily mean MADV and wind anomalies at $850 \mathrm{hPa}$ during phases 1,5 and 8 . The relative contributions of terms $1-3$ on the RHS of Eq. (1) to the MADV averaged over the SCCA offshore and inland regions during these three phases are shown in Fig. 14. In phase 1, the daily mean MADV over the SCCA offshore region is around $1.5 \times$ $\left.10^{-9} \mathrm{~kg} \mathrm{(kg} \mathrm{s}\right)^{-1}$ (Figs. 13a and 14a), while the MADV over the SCCA inland region is much stronger with 


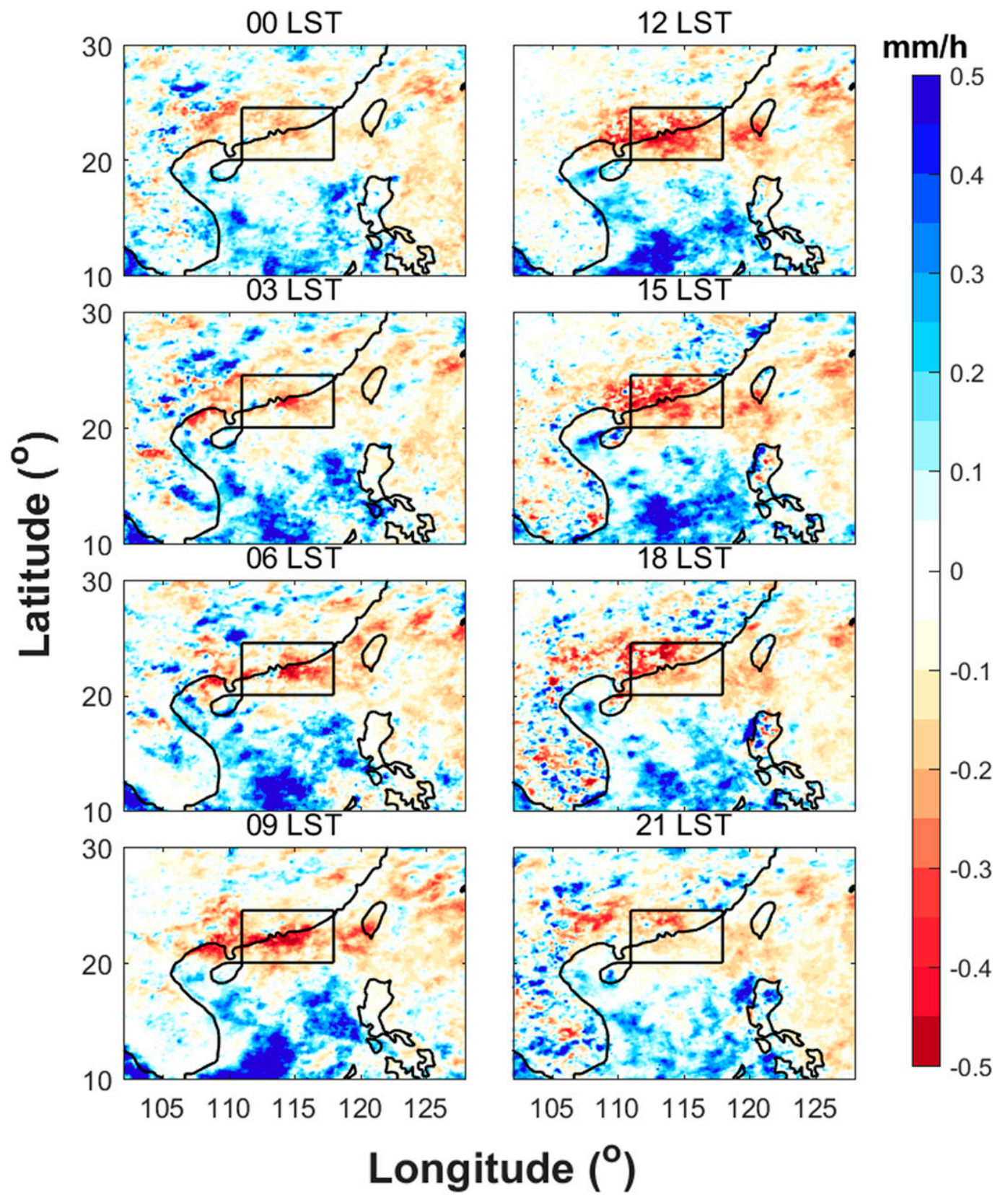

FIG. 11. As in Fig. 10, but for BSISO phase 5.

around $\left.6.5 \times 10^{-9} \mathrm{~kg} \mathrm{(kg} \mathrm{s}\right)^{-1}$ (Figs. 13a and 14b). The overall positive MADV indicates that the anomalous moisture advection associated with the BSISO transports relatively moister air to the SCCA during this phase, which promotes enhanced rainfall over the SCCA (Figs. 6 and 7). The strong positive MADV over the inland region specifically enhances the afternoon precipitation associated with the daytime sea breeze penetration and solar heating effects (Figs. 9 and 10). Both the advection of the background mean moisture by the BSISO anomalous wind and the advection of BSISO anomalous moisture by the background mean wind contribute to the positive inland MADV during the afternoon (Fig. 14b). The background mean atmospheric humidity is higher on the west side of the SCCA than that over the SCCA inland region. Hence, the anomalous westerly wind transports moisture from the west to the SCCA inland region (Figs. 13a). In addition, the mean southerly wind during the mei-yu season transports BSISO anomalous moisture from the SCCA offshore region to the inland region. Similarly, the positive MADV over the SCCA offshore region is also due to the 


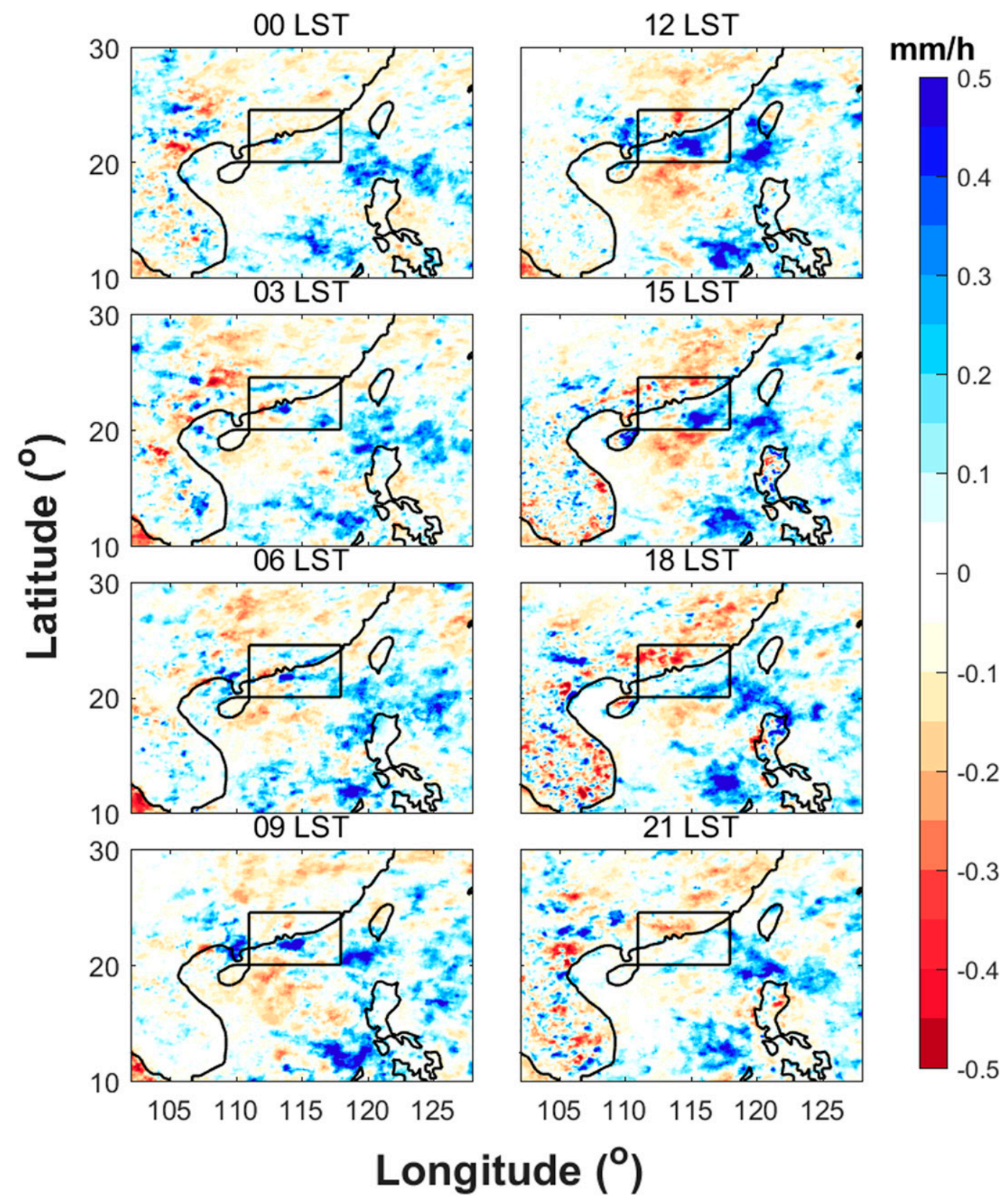

FIG. 12. As in Fig. 10, but for BSISO phase 8.

advection of the background mean moisture by the BSISO anomalous wind and the advection of the BSISO anomalous moisture by the background mean wind, while both terms are smaller when compared to their counterparts over the inland region (Fig. 14a).

During phase 5, both the SCCA offshore and inland regions are characterized by negative MADV (Fig. 13b). The negative anomalous moisture advection over the SCCA induces a suppression of the land-breeze related nocturnal rainfall and a suppression of the daytime inland rainfall associated with sea-breeze penetration and solar heating effects (Figs. 8, 9, and 11). The advection of the background mean moisture by the BSISO anomalous wind leads to the offshore negative MADV (Fig. 14c). The anomalous easterly wind transports relatively drier air from the west Pacific to the SCCA offshore region and weakens precipitation over the area. The negative MADV over the SCCA inland region is contributed both by the advection of the background mean moisture by the BSISO anomalous wind and the advection of the BSISO anomalous moisture by the background mean wind (Fig. 14d). In addition to the 


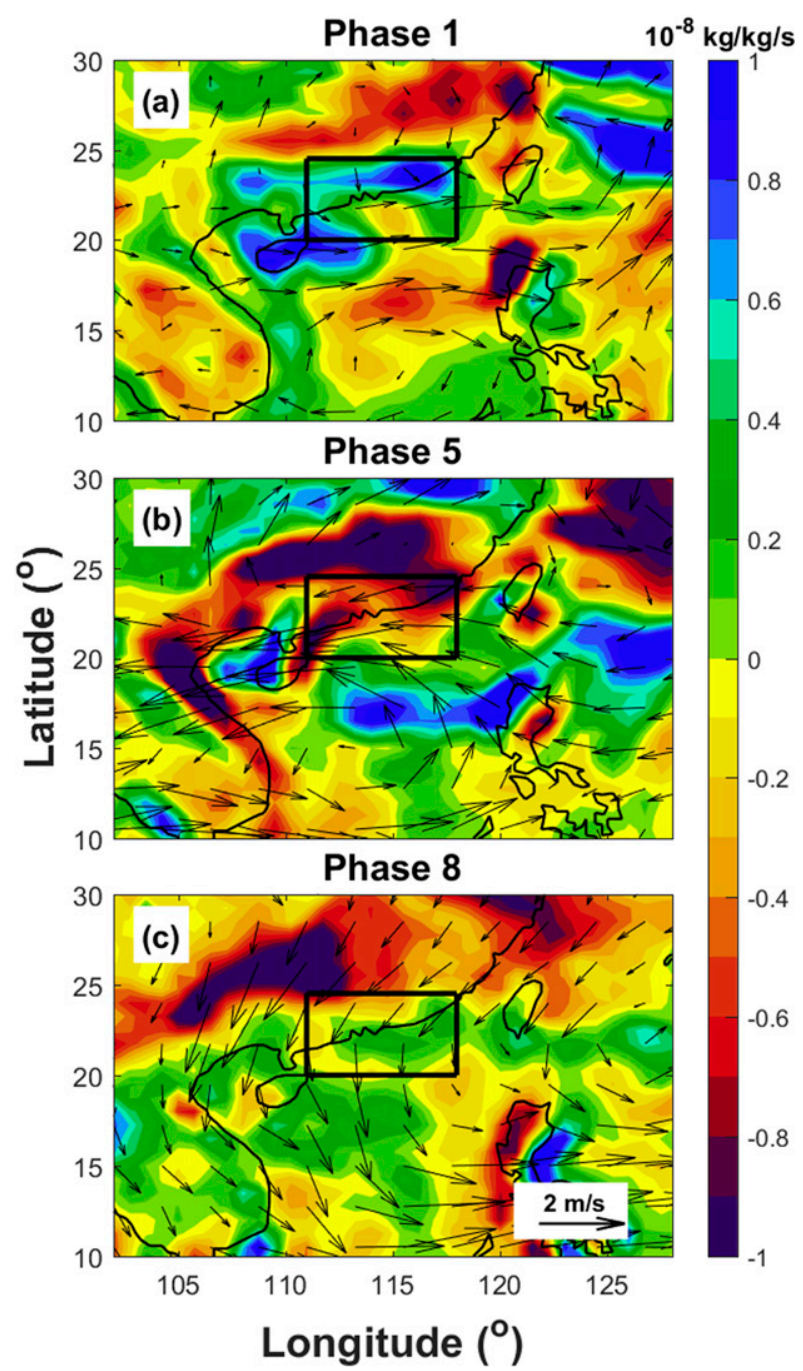

FIG. 13. Total anomalous horizontal moisture advection (color shading) and $850-\mathrm{hPa}$ wind anomalies (arrow) for BSISO phases (a) 1 , (b) 5 , and (c) 8 .

transportation of relatively drier air from the west $\mathrm{Pa}$ cific by the anomalous easterly flow (Fig. 13b), the background mean southerly wind also transport the BSISO anomalous direr air from ocean to the inland region (Figs. 2a and 11).

In phase 8 , the averaged MADV over the SCCA offshore region is positive (Figs. 13c and 14e), which corresponds to an enhanced offshore propagating rainfall feature from midnight to early afternoon (Figs. 8 and 12). This indicates that the positive anomalous moisture advection associated with the BSISO promotes enhanced and longer-lasting land-breeze-related precipitation during phase 8 . The advection of the background mean moisture by the BSISO anomalous wind is the major contributor to the positive offshore MADV. Over the inland region, the averaged MADV is negative during this phase (Fig. 14f). As a result, negative rainfall anomalies can be found over the SCCA inland region, with the suppression stronger in the afternoon around 1800 LST (Fig. 12). This negative inland MADV is largely due to the advection of the background mean moisture by the BSISO anomalous wind. This indicates that the BSISO anomalous northerly wind transports drier air from farther inland to the SCCA region.

To summarize the findings, the diurnal cycle of total rainfall over the SCCA offshore and inland regions during different BSISO phases is shown in Fig. 15. One should note that the differences of the total rainfall diurnal cycles between different BSISO phases include not only the impacts of the BSISO but also the impacts of the seasonal transitions, because the BSISO is closely related to the onset of the summer monsoon over the SCCA (e.g., Chi et al. 2015). Figure 15 shows several clear notable distinctions in the diurnal rainfall timing and intensity between different BSISO phases. For example, the inland afternoon rainfall peak (Fig. 15a) is enhanced dramatically in phase 1 $\left(\sim 0.7 \mathrm{~mm} \mathrm{~h}^{-1}\right)$ relative to the mei-yu seasonal mean $\left(\sim 0.5 \mathrm{~mm} \mathrm{~h}^{-1}\right)$, which is consistent with the diurnal cycle of inland rainfall anomalies during phase 1 as shown in Fig. 9. In phases 4 and 5, both the offshore morning rainfall peak and the inland afternoon rainfall peak are suppressed notably (Figs. 15a and 15b). These features are similar to the diurnal variations of the rainfall anomalies shown in Figs. 8 and 9. In phase 8 , the offshore rainfall peak is enhanced and peaks later when compared to the mei-yu seasonal mean. The stronger and later peak reflects stronger and longerlasting offshore-propagating rainfall associated with the land breeze, as noted above (Figs. 10 and 15a). On the other hand, inland rainfall is suppressed from early afternoon to evening in this phase (Figs. 9 and 15b).

\section{Summary and discussion}

In this study, we analyzed the modulations of the coastal mei-yu season (May-June) rainfall diurnal cycle over south China due to the boreal summer intraseasonal oscillation (BSISO), using 20-yr CMORPH rainfall observations, OLR data, and ERA-Interim reanalysis from 1998 to 2017. During the mei-yu season, the south China coastal area (SCCA) receives most of its annual rainfall and the majority of its extreme rainfall events, and is associated with a local rainfall maximum over the East Asian continent. Southwesterly monsoonal wind transports moisture from the South China Sea and Indochina to the SCCA and induces strong precipitation over the region. The diurnal cycle caused by the thermally forced land-sea breeze circulation is a dominant mode of rainfall variability in the mei-yu season, causing offshore rainfall in the morning in connection 


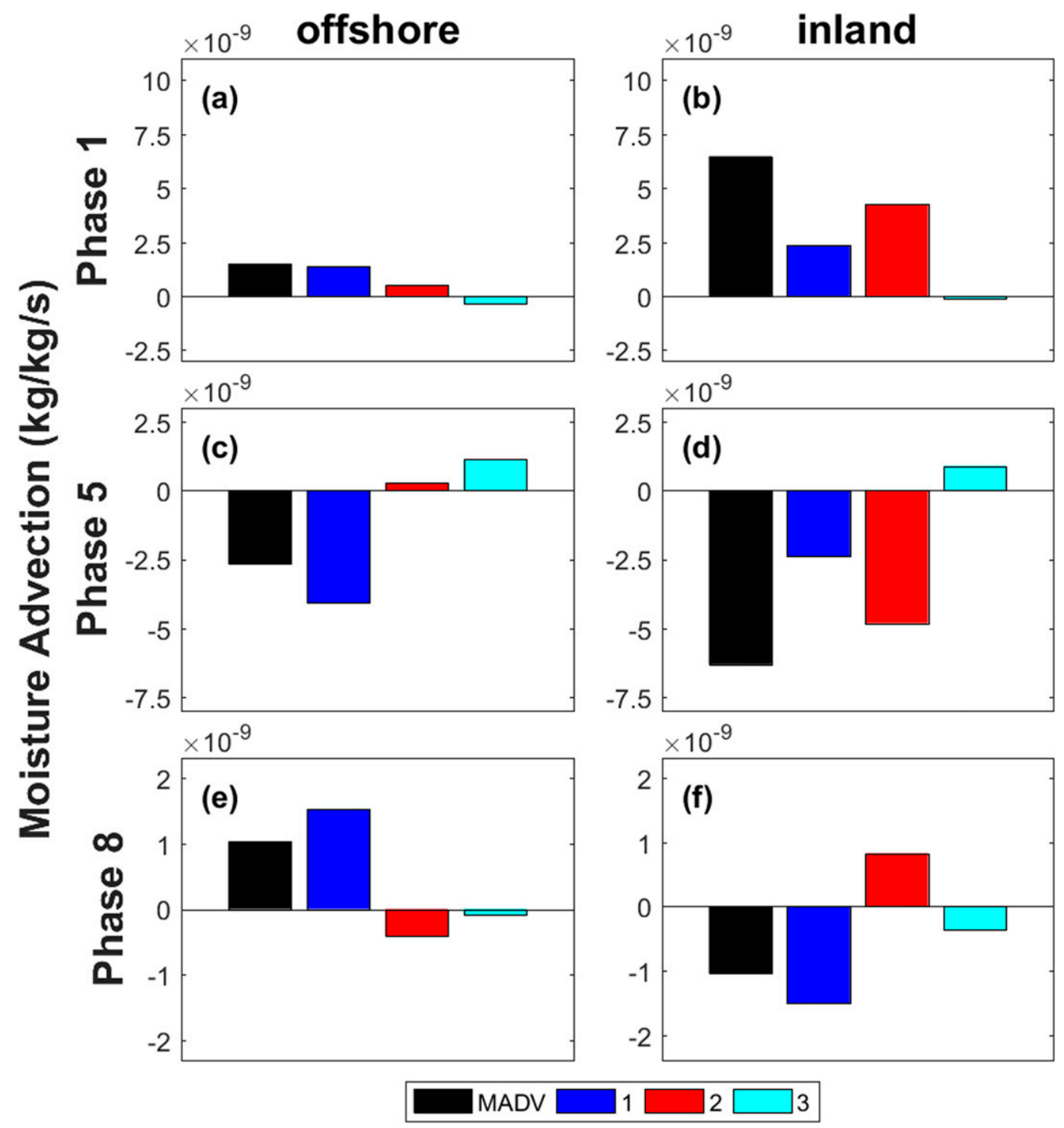

FIG. 14. The total intraseasonal horizontal moisture advection (MADV) and the three contributing terms-1) the advection of the background mean moisture by the BSISO anomalous wind; 2) the advection of the BSISO anomalous moisture by the background mean wind; and 3) the advection of the BSISO anomalous moisture by the BSISO anomalous wind - on the right-hand side of Eq. (1) for BSISO phases (top) 1, (middle) 5, and (bottom) 8 averaged over the (left) offshore and (right) inland regions of the SCCA.

with the land breeze, and inland rainfall in the afternoon due to the sea breeze and solar heating.

The BSISO is a northeastward-propagating feature in East Asia that strongly modulates rainfall on intraseasonal time scales during the mei-yu season through its modulation of the strength of the southwesterly flow and the meridional distribution of moisture. The northward propagation of the BSISO across the South China Sea and into China causes rainfall anomalies of up to $46 \%$ in magnitude relative to the mei-yu seasonal mean, which manifest in distinct manners depending the phase of the BSISO. In phase 1 of the BSISO, the rainfall enhancement over the SCCA inland region manifests in a prominent afternoon peak, which corresponds to a strengthening of the sea-breeze-related inland rainfall; however, the diurnal cycle of the positive rainfall anomalies offshore have much weaker diurnal variability. In phase 5, the inland negative rainfall anomalies have a minimum in the afternoon, while the offshore negative rainfall anomalies are characterized by a morning minimum. The rainfall in phase 8 is notably enhanced over the offshore region from the morning to the afternoon, which owes to a strengthened and longer-lasting offshore propagating rainfall feature associated with the 


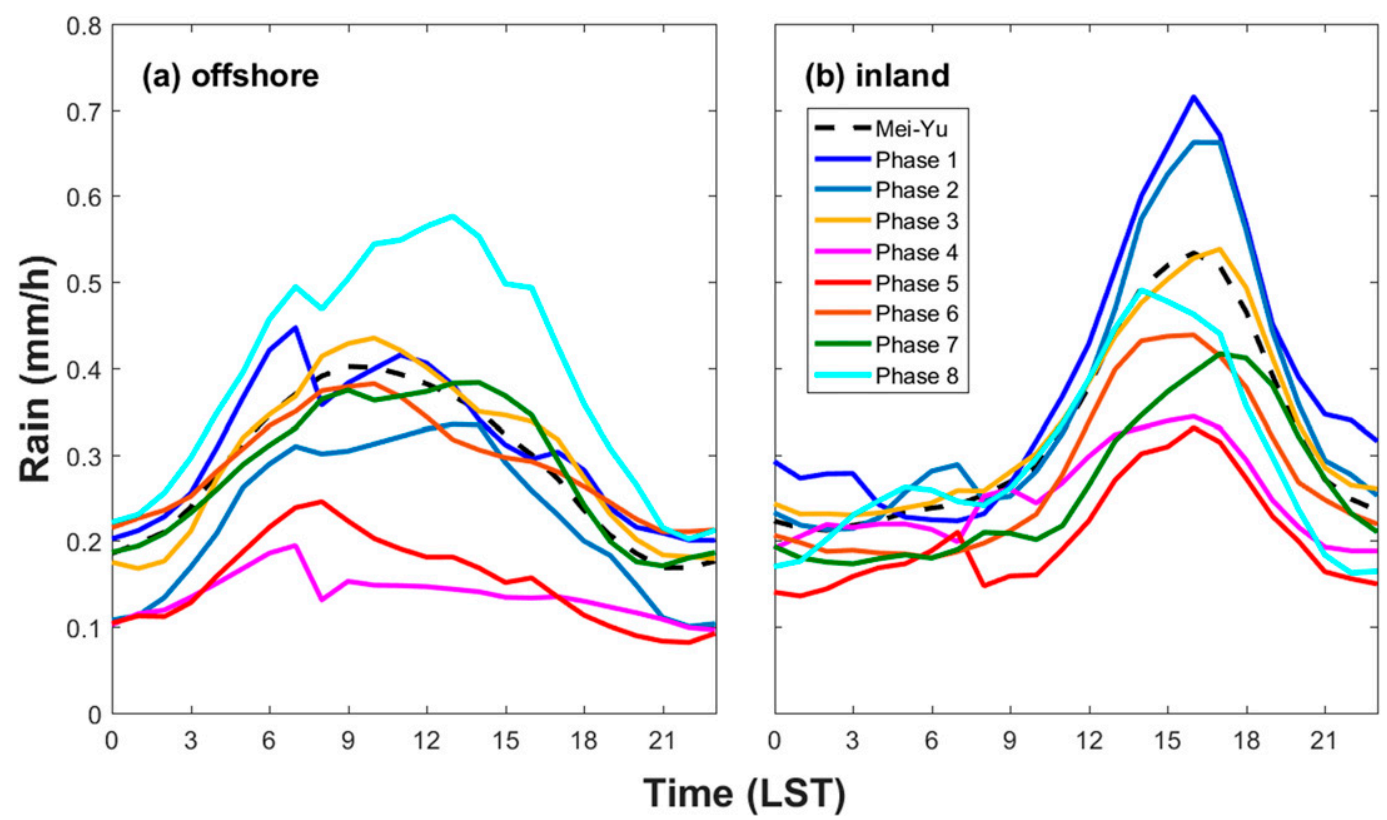

FIG. 15. The averaged diurnal cycles of hourly rainfall over the (a) offshore and (b) inland regions during the mei-yu season and each phase of the BSISO.

land breeze. Analysis of the horizontal moisture advection at $850 \mathrm{hPa}$ indicates that the diurnal cycle of rainfall anomalies during each BSISO phase can be understood through the influence of the BSISO on the low-level moisture distribution and flow.

The majority of the analysis in this study has been based on a combination of in situ rainfall observations and global reanalysis products. Given the inherent limitations of reanalysis products at fine spatiotemporal scales, future convection-permitting model analysis and sensitivity experiments would be valuable to further investigate the interactions between the local thermally forced diurnal cycle and the large-scale anomalous flows associated with the BSISO. In addition, coastal terrain has considerable impacts on the diurnal cycle of rainfall over the SCCA (Chen et al. 2016). It also would be valuable to study the orographic effects on the coastal rainfall diurnal cycles during different BSISO phases in the future. Future research is needed to further extend the current study to other coastal regions across Southeast Asia, whose rainfall diurnal cycles are closely related to the land-sea breeze circulation (e.g., Park et al. 2011; Qian et al. 2013; Wang and Sobel 2017). Because of differences in ambient wind direction and strength, coastal orography, and inland surface properties, among other factors, the modulations of coastal rainfall diurnal cycle caused by BSISO may differ across different coastal regions.

The diurnal cycle of rainfall is of major importance for climate at longer time scales because of its strong influence on the daily-mean radiative and water budgets and surface temperature (Bechtold et al. 2004). Although most general circulation models (GCMs) can reasonably predict the monthly (or even weekly) mean rainfall, it is still a big challenge for most GCMs to correctly simulate the rainfall diurnal cycle (Dai et al. 1999; Lin et al. 2000; Noda et al. 2012; Chen and Wang 2016). Studies like the current paper should help us better understand the dynamic connections between the regional diurnal cycle and low-frequency variability, and may therefore provide a useful benchmark for evaluating GCMs.

Acknowledgments. This study is partially supported by NSF Grants AGS-1305798 and 1712290, and the DOE subcontract to Penn State through the Pacific Northwest National Laboratory. Computing is partly performed at the Texas Advanced Computer Center. An animation of Fig. 4 can be downloaded from http://hfip.psu.edu/xzc55/ 500hpa_anomaly.gif. The authors thank the three anonymous reviewers for their detailed and valuable suggestions.

\section{REFERENCES}

Bechtold, P., J.-P. Chaboureau, A. Beljaars, A. K. Betts, M. Köhler, M. Miller, and J.-L. Redelsperger, 2004: The simulation of the diurnal cycle of convective precipitation over land in a global model. Quart. J. Roy. Meteor. Soc., 130, 31193137, https://doi.org/10.1256/qj.03.103.

Chen, G., and W.-C. Wang, 2016: An effective approach to evaluate GCM simulated diurnal variation of clouds. Geophys. Res. Lett., 43, 11 064-11 071, https://doi.org/10.1002/2016GL070446.

_ W. Wha, and T. Iwasaki, 2009: Diurnal variation of precipitation over southeastern China: 2. Impact of the diurnal 
monsoon variability. J. Geophys. Res., 114, D21105, https:// doi.org/10.1029/2009JD012181.

— , R. Lan, W. Zeng, H. Pan, and W. Li, 2018: Diurnal variations of rainfall in surface and satellite observations at the monsoon coast (south China). J. Climate, 31, 1703-1724, https://doi.org/ 10.1175/JCLI-D-17-0373.1.

Chen, S., W.-B. Li, Y.-D. Du, C.-Y. Mao, and L. Zhang, 2015: Urbanization effect on precipitation over the Pearl River Delta based on CMORPH data. Adv. Climate Change Res., 6 , 16-22, https://doi.org/10.1016/j.accre.2015.08.002.

Chen, X., K. Zhao, and M. Xue, 2014: Spatial and temporal characteristics of warm season convection over Pearl River Delta region, China, based on 3 years of operational radar data. J. Geophys. Res. Atmos., 119, 12 447-12 465, https://doi.org/10.1002/2014JD021965.

,,--- B. Zhou, X. Huang, and W. Xu, 2015: Radarobserved diurnal cycle and propagation of convection over the Pearl River delta during mei-yu season. J. Geophys. Res. Atmos., 120, 12 557-12 575, https://doi.org/10.1002/2015JD023872.

_ , F. Zhang, and K. Zhao, 2016: Diurnal variations of the land-sea breeze and its related precipitation over south China. J. Atmos. Sci., 73, 4793-4815, https://doi.org/10.1175/JAS-D-16-0106.1.

,-- , and -2017 : Influence of monsoonal wind speed and moisture content on intensity and diurnal variations of the mei-yu season coastal rainfall over south China. J. Atmos. Sci., 74, 2835-2856, https://doi.org/10.1175/JAS-D-17-0081.1.

Chi, Y., F. Zhang, W. Li, J. He, and Z. Guan, 2015: Correlation between the onset of the East Asian subtropical summer monsoon and the eastward propagation of the Madden-Julian Oscillation. J. Atmos. Sci., 72, 1200-1214, https://doi.org/ 10.1175/JAS-D-14-0038.1.

Dai, A., F. Giorgi, and K. E. Trenberth, 1999: Observed and modelsimulated diurnal cycles of precipitation over the contiguous United States. J. Geophys. Res., 104, 6377-6402, https://doi.org/ 10.1029/98JD02720.

Dee, D. P., and Coauthors, 2011: The ERA-Interim reanalysis: Configuration and performance of the data assimilation system. Quart. J. Roy. Meteor. Soc., 137, 553-597, https://doi.org/10.1002/qj.828.

Ding, Y., and J. C. L. Chan, 2005: The East Asian summer monsoon: An overview. Meteor. Atmos. Phys., 89, 117-142, https:// doi.org/10.1007/s00703-005-0125-z.

Du, Y., and G. Chen, 2018: Heavy rainfall associated with double low-level jets over southern China. Part I: Ensemble-based analysis. Mon. Wea. Rev., 146, 3827-3844, https://doi.org/ 10.1175/MWR-D-18-0101.1.

_ and R. Rotunno, 2018: Diurnal cycle of rainfall and winds near the south coast of China. J. Atmos. Sci., 75, 2065-2082, https://doi.org/10.1175/JAS-D-17-0397.1.

Hsu, P.-C., J.-Y. Lee, and K.-J. Ha, 2016: Influence of boreal summer intraseasonal oscillation on rainfall extremes in southern China. Int. J. Climatol., 36, 1403-1412, https://doi.org/10.1002/joc.4433.

Huang, L., Y. Luo, and D.-L. Zhang, 2018: The relationship between anomalous presummer extreme rainfall over south China and synoptic disturbances. J. Geophys. Res., 123, 33953413, https://doi.org/10.1002/2017JD028106.

Hung, C.-W., H.-J. Lin, and H.-H. Hsu, 2014: Madden-Julian oscillation and the winter rainfall in Taiwan. J. Climate, 27, 45214530, https://doi.org/10.1175/JCLI-D-13-00435.1.

Jiang, Z., D.-L. Zhang, R. Xia, and T. Qian, 2017: Diurnal variations of presummer rainfall over southern China. J. Climate, 30, 755-773, https://doi.org/10.1175/JCLI-D-15-0666.1.

Joyce, R. J., J. E. Janowiak, P. A. Arkin, and P. Xie, 2004: CMORPH: A method that produces global precipitation estimates from passive microwave and infrared data at high spatial and temporal resolution. J. Hydrometeor., 5, 487-503, https://doi.org/10.1175/ 1525-7541(2004)005<0487:CAMTPG > 2.0.CO;2.

Kerns, B. W. J., Y.-L. Chen, and M.-Y. Chang, 2010: The diurnal cycle of winds, rain, and clouds over Taiwan during the mei-yu, summer, and autumn rainfall regimes. Mon. Wea. Rev., 138, 497-516, https://doi.org/10.1175/2009MWR3031.1.

Kiladis, G. N., J. Dias, K.H. Straub, M.C. Wheeler, S.N. Tulich, K. Kikuchi, K.M. Weickmann, and M.J. Ventrice, 2014: A comparison of OLR and circulation-based indices for tracking the MJO. Mon. Wea. Rev., 142, 1697-1715, https://doi.org/ 10.1175/MWR-D-13-00301.1.

Lau, W. K., D. E. Waliser, and B. Goswami, 2012: South Asian monsoon. Intraseasonal Variability in the Atmosphere-Ocean Climate System, W. K. Lau and D. E. Waliser, Eds., Springer, 21-72.

Lee, H.-T., A. Gruber, R. G. Ellingson, and I. Laszlo, 2007: Development of the HIRS outgoing longwave radiation climate dataset. J. Atmos. Oceanic Technol., 24, 2029-2047, https:// doi.org/10.1175/2007JTECHA989.1.

Li, W., S. Chen, G. Chen, W. Sha, C. Luo, Y. Feng, Z. Wen, and B. Wang, 2011: Urbanization signatures in strong versus weak precipitation over the Pearl River delta metropolitan regions of China. Environ. Res. Lett., 6, 034020, https://doi.org/ 10.1088/1748-9326/6/3/034020.

Lin, X., D. A. Randall, and L. D. Fowler, 2000: Diurnal variability of the hydrologic cycle and radiative fluxes: Comparisons between observations and a GCM. J. Climate, 13, 4159-4179, https://doi.org/ 10.1175/1520-0442(2000)013<4159:DVOTHC > 2.0.CO;2.

Luo, Y., H. Wang, R. Zhang, W. Qian, and Z. Luo, 2013: Comparison of rainfall characteristics and convective properties of monsoon precipitation systems over south China and the Yangtze and Huai River basin. J. Climate, 26, 110-132, https:// doi.org/10.1175/JCLI-D-12-00100.1.

- and Coauthors, 2017: The Southern China Monsoon Rainfall Experiment (SCMREX). Bull. Amer. Meteor. Soc., 98, 9991013, https://doi.org/10.1175/BAMS-D-15-00235.1.

Madden, R. A., and P. R. Julian, 1971: Detection of a 40-50 day oscillation in the zonal wind in the tropical Pacific. J. Atmos. Sci., 28, 702-708, https://doi.org/10.1175/1520-0469(1971)028<0702: DOADOI $>2.0 . \mathrm{CO} ; 2$

$\longrightarrow$, and — 1972: Description of global-scale circulation cells in the tropics with a $40-50$ day period. J. Atmos. Sci., 29, 1109-1123, https://doi.org/10.1175/1520-0469(1972)029<1109: DOGSCC $>2.0 . \mathrm{CO} ; 2$.

Noda, A. T., K. Oouchi, M. Satoh, and H. Tomita, 2012: Quantitative assessment of diurnal variation of tropical convection simulated by a global nonhydrostatic model without cumulus parameterization. J. Climate, 25, 5119-5134, https://doi.org/ 10.1175/JCLI-D-11-00295.1.

Park, M.-S., C.-H. Ho, J. Kim, and R. L. Elsberry, 2011: Diurnal circulations and their multi-scale interaction leading to rainfall over the South China Sea upstream of the Philippines during intraseasonal monsoon westerly wind bursts. Climate Dyn., 37, 14831499, https://doi.org/10.1007/s00382-010-0922-z.

Qian, J.-H., A. W. Robertson, and V. Moron, 2013: Diurnal cycle in different weather regimes and rainfall variability over Borneo associated with ENSO. J. Climate, 26, 1772-1790, https://doi.org/ 10.1175/JCLI-D-12-00178.1.

Rauniyar, S. P., and K. J. E. Walsh, 2011: Scale interaction of the diurnal cycle of rainfall over the Maritime Continent and Australia: Influence of the MJO. J. Climate, 24, 325-348, https://doi.org/10.1175/2010JCLI3673.1.

Ren, P., H.-L. Ren, J.-X. Fu, J. Wu, and L. Du, 2018: Impact of boreal summer intraseasonal oscillation on rainfall extremes in 
southeastern China and its predictability in CFSv2. J. Geophys. Res., 123, 4423-4442, https://doi.org/10.1029/2017JD028043.

Ruppert, J. H., R. H. Johnson, and A. K. Rowe, 2013: Diurnal circulations and rainfall in Taiwan during SoWMEX/TiMREX (2008). Mon. Wea. Rev., 141, 3851-3872, https://doi.org/ 10.1175/MWR-D-12-00301.1.

Slingo, J., P. Inness, R. Neale, S. Woolnough, and G. Yang, 2003: Scale interactions on diurnal to seasonal time scales and their relevance to model systematic errors. Ann. Geophys., 46, 139155, https://doi.org/10.4401/ag-3383.

Wang, B., and H. Rui, 1990: Synoptic climatology of transient tropical intraseasonal convection anomalies: 19751985. Meteor. Atmos. Phys., 44, 43-61, https://doi.org/10.1007/ BF01026810,

— seasonal oscillation. J. Atmos. Sci., 54, 72-86, https://doi.org/ 10.1175/1520-0469(1997)054<0072:AMFTBS>2.0.CO;2.

Wang, H., Y. Luo, and B. J.-D. Jou, 2014: Initiation, maintenance, and properties of convection in an extreme rainfall event during SCMREX: Observational analysis. J. Geophys. Res., 119, 13 206-13 232, https://doi.org/10.1002/2014JD022339.

Wang, S., and A. H. Sobel, 2017: Factors controlling rain on small tropical islands: Diurnal cycle, large-scale wind speed, and topography. J. Atmos. Sci., 74, 3515-3532, https://doi.org/10.1175/ JAS-D-16-0344.1.

, D. Ma, A. H. Sobel, and M. K. Tippett, 2018: Propagation characteristics of BSISO indices. Geophys. Res. Lett., 45, 9934-9943, https://doi.org/10.1029/2018GL078321.

$\mathrm{Xu}, \mathrm{W}$., and S. A. Rutledge, 2018: Convective variability associated with the boreal summer intraseasonal oscillation in the South China Sea region. J. Climate, 31, 7363-7383, https://doi.org/ 10.1175/JCLI-D-18-0091.1.
_ E. J. Zipser, and C. Liu, 2009: Rainfall characteristics and convective properties of mei-yu precipitation systems over south China, Taiwan, and the South China Sea. Part I: TRMM observations. Mon. Wea. Rev., 137, 4261-4275, https://doi.org/ 10.1175/2009MWR2982.1.

Zhang, L., B. Wang, and Q. Zeng, 2009: Impact of the Madden-Julian oscillation on summer rainfall in southeast China. J. Climate, 22 201-216, https://doi.org/10.1175/2008JCLI1959.1.

Zhang, M., and Z. Meng, 2018: Impact of synoptic-scale factors on rainfall forecast in different stages of a persistent heavy rainfall event in south China. J. Geophys. Res. Atmos., 123, 35743593, https://doi.org/10.1002/2017JD028155.

Zheng, Y., M. Xue, B. Li, J. Chen, and Z. Tao, 2016: Spatial characteristics of extreme rainfall over China with hourly through 24-hour accumulation periods based on national-level hourly rain gauge data. Adv. Atmos. Sci., 33, 1218-1232, https://doi.org/10.1007/s00376-016-6128-5.

Zhou, T., R. Yu, H. Chen, A. Dai, and Y. Pan, 2008: Summer precipitation frequency, intensity, and diurnal cycle over China: A comparison of satellite data with rain gauge observations. J. Climate, 21, 3997-4010, https://doi.org/10.1175/2008JCLI2028.1.

Zhou, W., and J. C. L. Chan, 2005: Intraseasonal oscillations and the South China Sea summer monsoon onset. Int. J. Climatol., 25, 1585-1609, https://doi.org/10.1002/joc.1209.

Zhu, B., and B. Wang, 1993: The 30-60-day convection seesaw between the tropical Indian and western Pacific Oceans. J. Atmos. Sci., 50, 184-199, https://doi.org/10.1175/1520-0469 (1993) $050<0184:$ TDCSBT $>2.0$. CO;2.

Zhu, L., Z. Meng, F. Zhang, and P. M. Markowski, 2017: The influence of sea- and land-breeze circulations on the diurnal variability in precipitation over a tropical island. Atmos. Chem. Phys., 17, 13 213-13 232, https://doi.org/10.5194/acp-17-13213-2017. 